\title{
OBNOVA TORZ ARCHITEKTÚRY AKO ŠPECIALIZOVANÁ ARCHITEKTONICKÁ DISCIPLÍNA
}

\author{
JANA GREGOROVÁ - LÝDIA CHOVANCOVÁ - ZUZANA ONDREJKOVÁ - \\ ALEXANDRA S̆KRINÁROVÁ
}

\begin{abstract}
Abstrakt: Predpokladom optimálnej prezentácie archeologických nálezísk je koordinácia všetkých profesii. Vhodným začlenením špecializovaného architekta do procesu obnovy je možné ovplyvnit' stratégiu vykonávania archeologických výskumov, ako aj prezentáciu a prípadnú ochranu originálu. Takýto architekt okrem iného pracuje s torzom architektúry ako s umelecko-tektonickým exponátom. Ak je súčastou špecializácie aj vyhodnocovanie zrealizovaných obnov torz architektúry, proces obnovy je možné na základe ziskaných a následne objektivizovaných poznatkov optimalizovat'.
\end{abstract}

Kl'účové slová: obnova - prezentácia - architekt-torzo-krycia stavba-hrad-mestské opevnenie.

\section{Restoration of Ruins of Architecture as a Specialized Architectural Discipline}

Abstract: The optimum presenting of archaeological sites is conditioned by the coordination of all the professions involved. The employment of a specialized architect in the restoration process can positively influence the strategy of archaeological research, as well as the presentation and possible protection of the original constructions. In addition, specialized architects approach ruins of architecture as art-tectonic exhibits. If their specialization includes the assessment of the executed restorations of architectural ruins, the restoration process can be optimised on the basis of the acquired and objectified information.

Key words: restoration - presentation - architect-ruin-enclosure building-castle - urban fortification.

\section{Úvod}

Pod pojmom ruina rozumieme „stavbu, ktorá stratila konštrukcie tvoriace jej prirodzenú ochranu (strecha, okná, omietky a i.), čim je vystavená negatívnym atmosférickým vplyvom, čo má za následok jej zvýšené podliehanie deštruktivnemu účinku času. Je to stavba, ktorá prestala plnit'svoju funkciu, prestala byt' ochranou pre l'udské aktivity a z ktorej začalo postupne ubúdat' až po jej úplný zánik." (Ashurst 2007, XX) Proces deštrukcie plne funkčnej stavby na ruinu sa môže diat' postupne alebo náhle, napríklad kolapsom stavby, zemetrasením, vojnou a pod. Výraz proces deštrukcie stavby je významovo porovnatel'ný s procesom archeologizácie používaným $\mathrm{v}$ archeológii (tab. I). Potom pojem torzo môžeme chápat' vo vzt’ahu k pamiatkovej starostlivosti ako „ruinu po úprave, ktorej spôsob urči rámcová metóda pamiatkovej obnovy. Pri narušených objektoch sa zámerne necháva vyzniet’ nepravidelný tvar deštruovaného objektu, ktorý je konsolidovaný a estetizovaný. “ (Gregorová 2007, 66)

Na Slovensku tvoria viac ako polovicu architektúr v stave ruiny hrady v prírodnom prostredí, ale môžu sa ňou stat' objekty akéhokolvvek typologického druhu.

V predkladanom príspevku sa pokúsime charakterizovat' špecifickost' profesie architekta, získanú práve zohl'adňovaním narušenosti pôvodne ucelených stavieb, areálov, prípadne celých urbanistických systémov, ktoré sa nachádzajú bud' v urbanizovaných, alebo krajinných kontextoch. Okrem všeobecnej charakteristiky daných problémov bude v kontexte príspevku predstavené aj modelové riešenie návrhu komplexnej obnovy mestského opevnenia v Pamiatkovej zóne Modra, na ktorom sa podiel'ali niektorí členovia autorského kolektívu v rokoch 2012-2014. $\mathrm{V}$ druhej časti príspevku budú prezentované čiastkové výsledky rozpracovaných doktorandských tém vypísaných na Fakulte architektúry STU v Bratislave v súvislosti s problematikou obnovy torz architektúry. 


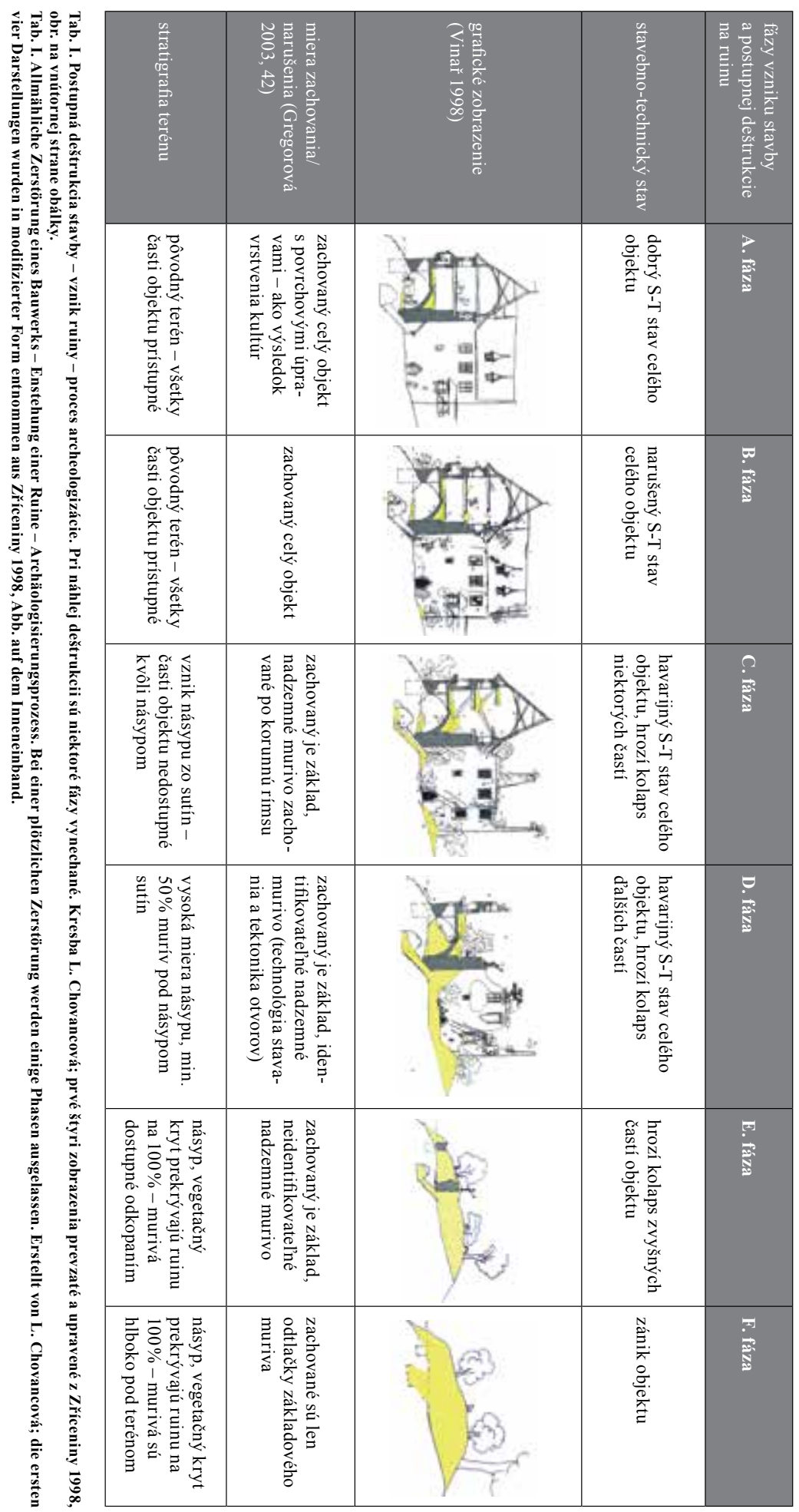




\section{Problematika špecializácie architekta na obnovu pamiatok}

Pri projektovaní obnovy pamiatok sa architekt stretáva so zložitou situáciou, ktorá vyplýva zo špecifickosti zadania. Musí projektovat' tak, aby sa pamiatka prezentovala citlivo a zrozumitel'ne, a zároveň zostala maximálne zachovaná jej autenticita. Na rozdiel od iných zadaní, kde je prvoradé produkovat' nové nápady a prezentovat' svoju kreativitu, pamiatky je nutné chápat' ako exponáty a tak sa k nim aj postavit'. Pre danú činnost' je potrebný architekt so špeciálnym vzdelaním. Prax však ani na Slovensku, ani v Čechách špecialistov tohto druhu v radoch architektov nevyžaduje. Tento problém je evidentný pri obnove zachovaných architektonických pamiatok aj pri torzách architektúry, ktoré sú predmetom záujmu pri prezentácii archeologických lokalít.

Na výskumnú a metodickú činnost' sú v zmysle pamiatkového zákona ${ }^{1}$ požadované adekvátne znalosti. Táto skutočnost' sa prejavuje v praxi pozitívne tým, že sa výrazne zvýšila kvalita vykonávania pamiatkových výskumov a systematizuje sa ich evidencia. Horšia situácia je práve na poli architektonickom, kde pre vyhotovenie relevantnej projektovej dokumentácie (podl'a ktorej sa samotná pamiatková obnova realizuje) netreba mat’ špecifické znalosti.

Absencia architektov v obci pamiatkarov spôsobuje, že regulácia obnovy máva zväčša čiastkový charakter, venujúci sa výlučne ochrane pamiatkových hodnôt. Regulácia sa týka najmä ochrany fyzickej podstaty originálu, ale menej kontextu, v ktorom sa originál nachádza. Najväčší problém vzniká pri stanovení miery direktívnosti regulácie dotvorenia zaniknutých častí pamiatky. Často sa nedefinujú rámce toho, ako má nový zásah vyzerat'. Chýba profesia metodika, ktorý dokáže nadefinovat' tzv. rámcovú metódu pamiatkovej obnovy, podla ktorej je nutné pamiatku so všetkými profesiami aj po etapách obnovovat'.

Absencia pamiatkarov v obci architektov bez presnejšieho regulovania zasa spôsobuje, že dotvorenie chýbajúcich častí pamiatkových štruktúr sa stane výlučne doménou architektov, ktorí kontinuitu tradície nechápu ako hodnotu. Pri takomto postoji sa potom programovo vytvárajú aj na plochách stavebných prieluk v pamiatkovo chránených územiach kontrastné novotvary (napr. situácia pripravovanej obnovy Podhradia v Bratislave, kde sa pôvodne homogénne prostredie začína pretvárat' na heterogénne, prípadne sa začínajú zastavovat' územia, ktoré by mali ostat' nezastavané).

Je zrejmé, že extrémne postoje pamiatkarov a architektov danej situácii nepomôžu. Spomínané problémy sa prejavia ešte intenzívnejšie, ak sa obnova týka objektov, ktoré sa z rôznych dôvodov ocitli v stave ruiny. V týchto prípadoch sa kladú vysoké nároky na stanovenie rozsahu plošných výskumov, ktoré je nutné vykonat', aby sa získali čo najkomplexnejšie informácie o pamiatke. Častejšie sa však pamiatka skúma po etapách. Potom je potrebné počítat' s tým, že sa v d’alšej etape výskumu zistí niečo nepredvídané. Celý proces si vyžaduje stanovenie optimálnej stratégie. Býva spravidla dlhodobý, st’ažený nedostupnostou, komplikovanou stratigrafiou nálezu a vysokou mierou deštrukcie originálu.

Výchova špecialistov na problematiku obnovy torz architektúry vznikla ako reakcia na výrazný rozmach obnovy torz architektúry v poslednom desat'ročí na Slovensku. Od roku 2002 sa na Fakulte architektúry STU v Bratislave začala systematická výučba architektov so zameraním na obnovu torz architektúry (Gregorová 2002). Boli vydané skriptá (Gregorová a kol. 2003; Gregorová-Gregor a kol. 2008), príspevky publikované v odborných časopisoch, ${ }^{2}$ problematika bola prednášaná na vedeckých konferenciách. ${ }^{3} \mathrm{Na}$ základe spolupráce s pracovníkmi príslušných Krajských pamiatkových úradov (d’alej len KPÚ) sa projektujú významné archeologické

1 Zákon NR SR č.49/2002 Z. z. o ochrane pamiatkového fondu, posledná novela účinná od 1. 7. 2014.

2 Torzá boli ako čiastková téma zapracované do monotematicky postavených čísel (odborný garant J. Gregorová) architektonických časopisov Projekt 5/6, 2007, s nosnou témou Odkial' prichádzame, kam sa uberáme (ocenený cenou Pamiatky a múzeá v kategórii drobná tlač za rok 2007); Projekt 4/5, 2011 s nosnou témou Obnova hradov a časopis Urbanita 2/2012 s nosnou témou Pamiatková ochrana.

3 Prezentácia torz architektúry bola predstavená aj na viacerých odborných fórach. Gregorová, J.-Baxa, P.-Paulíny, P.-Poláček, L.-Ilkovič, J., Nominácia pamiatok Vel'kej Moravy k zápisu na Zoznam svetového kultúrneho dedičstva UNESCO, Bardkontakt, august 2006, Bardejov; Gregorová, J., Návrh archeologicko-architektonického parku Kopčany-Mikulčice, na konferencii Slovensko-rakúska platforma na rekonštrukciu žrebčína v Kopčanoch, 2007, Kopčany; Gregorová, J., Prehodnotenie spôsobu prezentácie ruín architektúry vo vzt’ahu k autenticite originálu. Medzinárodná konferencia - Počiatky pamiatkovej ochrany hradných zrúcanín, november 2009, Nitra; Gregorová, J., Prípravná architektonickourbanistická dokumentácia - jej význam pri návrhu prezentácie archeologického náleziska, Medzinárodná konferencia archeológie stredoveku mesto v stredoveku a jeho zázemie, AÚ SAV Nitra, september 2011, Modra. 
lokality, často aj nadnárodného významu. ${ }^{4} \mathrm{Na}$ danú problematiku sú vypisované doktorandské témy, ktoré riešia čiastkové problémy súvisiace s prezentáciou torz architektúry. Zaoberajú sa rôznymi metódami pamiatkovej obnovy torz, analýzou stavu obnovy hradov na území Slovenska či pasportom mestských opevnení. Skúmanie hradov z hl'adiska uplatňovania rôznych spôsobov obnovy nebolo doteraz systematizované a predstavuje túto atraktívnu tému aj z hladiska podielu architekta na procese obnovy. Návrh pasportizácie mestských opevnení s prevládajúcim stredovekým charakterom vytvára nové možnosti prístupu k zhodnoteniu stavu opevnení miest. Tie boli doteraz často opomínané, prípadne neboli dostatočne podrobne spracované ani pri zhotovovaní Zásad pamiatkovej starostlivosti, ktoré predstavujú základný koncepčný nástroj pre koordinovanie obnovy pamiatkovo chránených území. ${ }^{5}$

\section{Úloha architekta v procese obnovy pamiatok}

Úloha architekta má v každej etape obnovy pamiatky svoje špecifické miesto. Komplexnost' profesie sa využíva vo fáze výkonu pamiatkových výskumov, ich interpretácie, návrhu metódy obnovy, vypracovania projektovej dokumentácie, ako aj autorskom dozore pri samotnej realizácii.

Z uvedeného vyplýva, že architekt je súčastou interdisciplinárneho tímu, ktorého hlavným ciel'om je navrhnút' a zrealizovat' optimálnu obnovu pamiatky s dôrazom na maximálne zachovanie autenticity a zrozumitel’nosti pri prezentácii pamiatky. Zároveň je tým subjektom, ktorý počas spracovania príslušného stupňa projektovej dokumentácie zabezpečí kontinuitu s už rozpracovanými územnými plánmi či inými typmi projektovej dokumentácie.

Architekt vo výskumnom tíme je potrebný pri interpretácii architektonických dimenzií zničených aj zachovaných objektov, súborov a sídel. Architekt v tíme spracovávajúcom pasportizáciu už zrealizovaných obnov môže uplatňovat' svoje profesijné kritériá pri hodnotení obnovených pamiatok, vyplývajúce $\mathrm{z}$ hodnotenia torza ako pozostatku tektonického objektu, plniaceho v dobe svojho vzniku určitú funkciu.

Architekt $\mathrm{v}$ úlohe metodika je potrebný pri návrhu optimálnej prezentácie zachovanej či narušenej architektúry. Je autorom rámcovej metódy pamiatkovej obnovy, ktorá stanoví, akým spôsobom sa pozostatky architektúry budú prezentovat' (iba sa zakonzervujú, čiastočne sa rekonštruujú metódou architektonizovanej ruiny, znovu sa poskladajú opracované kamenné články metódou anastylózy a i.). Architekt je zodpovedný aj za to, že pozostatky architektonického diela budú tektonicky prezentované v tvare torza, a nie ako neidentifikovaná „hŕba“ kamenia, ktorej tvar vznikol náhodne.

Architekt $v$ úlohe projektanta musí prezentáciu archeologického nálezu vnímat' a následne riešit' v urbanistickej, ako aj architektonickej dimenzii.

Z urbanistického hladiska je potrebné brat' do úvahy, či sa archeologické lokality nachádzajú v urbanizovanej alebo prírodnej krajine. Typ prostredia je určujúcim determinantom pre sta-

\footnotetext{
4 Takto interpretovaná problematika prezentácie torz architektúry bola využitá aj pri projektovaní významných archeologických lokalít národného a nadnárodného významu: Gregorová, J.-Gregor, P.-Paulíny, P.- Škrovina, M.-Vaščák. M., Ochrana a záchrana archeologických a historických pamiatok na Slovensku ako súčast' európskeho kultúrneho dedičstva, Štátna výskumná úloha SAV 50/2003. V rámci výskumu bol vypracovaný aj projekt prezentácie ranostredovekého valu v kazemate Nitrianskeho hradu, za ktorý kolektív získal ocenenie CE.ZA.AR v roku 2007; Gregorová, J.-Staník, I.-Gregor, P.-Ďurko, P., Pamiatková obnova severnej časti východného úseku hradbového múru v MPR Trnava, realizačný projekt 2004, realizácia 2006; Gregorová, J.-Paulíny, P.-Ilkovič, J., Architektonicko-urbanistická štúdia archeologického parku Mikulčice-Kopčany, vypracovaný pre účely Nominačného spisu na zápis česko-slovenského územia s architektúrami Vel'kej Moravy na listinu svetového dedičstva, 2006; Gregorová, J.-Paulíny, P. a kol., Pamiatková obnova častí objektu NKP Kostola sv. Margity Antiochijskej s cintorínom v Kopčanoch, Bratislava, 2008; Gregorová J.-Kyjovská, V.-Makýš, O.-Ruttkay, A., Pamiatková obnova NKP archeologická lokalita Rotunda, vel'komoravský dvorec Kostolec v Ducovom, 2009, Projekt financovaný MK SR - grant Obnovme si svoj dom; Gregorová J.-Petrášová, S.Makýš, O., Prezentácia archeologickej lokality zaniknutého Kostola sv. Michala v Podhoranoch, 2012, projekt financovaný MK SR - grant Obnovme si svoj dom; Gregorová, J.-Kohút, V.-Petrášová, S.-Staník, I.-Škrinárová, A., Vypracovanie predprojektovej prípravy pre začatie obnovy NKP mestského opevnenia v Modre, 2013; Gregorová, J.-Kyjovská, V., NKP hradisko Molpír, Návrh revitalizácie archeologickej lokality, architektonická štúdia, 2014.

5 Na danú problematiku sú na Fakulte architektúry STU v Bratislave vypisované doktorandské témy, ktoré riešia čiastkové problémy súvisiace s prezentáciou torz architektúry. Uvádzame aspoň niektoré z nich: Kyjovská, V., Neinvazívne spôsoby prezentácie ruín architektúry - virtuálna prezentácia zanikajúcej architektúry (2012); Chovancová, L., Ochranné konštrukcie a krycie stavby torz architektúry; Škrinárová, A., Obnova stredovekých mestských opevnení na území Slovenska; Ondrejková, Z., Obnova hradov na území Slovenska; Palgutová, K., Analytická metóda prezentácie pamiatok a jej potenciál v procese architektonickej tvorby (2014).
} 
novenie spôsobu prezentácie archeologického náleziska. Dôležitým je aj zohl’adnenie terénu, zelene a stratigrafie nálezu vo vzt’ahu k ruine pamiatkovej štruktúry.

$\mathrm{Z}$ architektonického hl'adiska je vo vzt’ahu k prostrediu nutné počítat's vyhĺbením jamy za účelom prezentácie pamiatky in situ bez prekrytia; s možnostou návrhu krycej konštrukcie, ktorou by mal byt' archeologický nález zabezpečený pred klimatickými vplyvmi; prípadne s možnostou využitia archeologického nálezu (chápaného ako exponát alebo ako funkčný objekt).

\section{Špecifický prístup architekta $k$ obnove torz architektúry}

Špecializácia profesie architekta v danej problematike sa prejavuje vo vykonávaní viacerých atypických postupov. Vymenujeme aspoň niektoré z nich:

- hodnotene metodík a pasport už zrealizovaných obnov (pre permanentný monitoring a objektivizáciu postupov pri d’alších obnovách),

- konštrukcia hypotetických rekonštrukcií (pre vedecké účely a názornú predstavu o podobe zaniknutých štruktúr na základe znalostí tradičnej tektoniky stavieb),

- stanovenie rámcovej metódy pamiatkovej obnovy (pre zabezpečenie kontinuálnej obnovy podl'a jednotne stanovených pravidiel),

- návrh ideí obnovy formou variantných riešení (pre objektivizáciu výberu riešenia, zodpovedajúceho požiadavkám všetkých zúčastnených strán procesu obnovy),

- návrh stratégie obnovy (pre skoordinovanie celého procesu vybraného variantu obnovy),

- vypracovanie všetkých stupňov projektovej dokumentácie, vrátane územných plánov (pre vytvorenie nástroja na kvalitnú realizáciu obnovy, či na koordinovanie stavebnej činnosti na archeologickej lokalite ako na pamiatkovo chránenom území na základe znalostí o interdisciplinarite celého procesu),

- uplatňovanie autorského dozoru (pre zabezpečenie kontinuity medzi autormi návrhu obnovy a realizátormi, ktorí sú špecializovaní na výkon obnovy).

Tieto špecifické postupy boli využité pri predprojektovej príprave pre komplexnú obnovu mestského opevnenia v pamiatkovej zóne Modra, spracovanej v rokoch 2012-2014 na Fakulte architektúry STU v Bratislave. Dlhodobý nezáujem o obnovu historického mesta a mestského opevnenia spôsobil, že sa nachádzajú v nevyhovujúcom stave, znehodnotené nevhodnou zástavbou, bez prezentácie hodnotných častí. Vypracovaný materiál by mal začat' koncepčnú obnovu opevnenia ako identického urbanistického súboru, vymedzujúceho historické mesto z okolitej krajiny. Variantné riešenia prezentácie poslúžia na výber reálneho spôsobu obnovy, zodpovedajúceho predstavám obyvatel'om mesta aj požiadavkám pamiatkovej ochrany. Všetky varianty počítajú s prezentáciou zachovaných častí opevnenia z doby jeho funkčnosti (ide o renesančné bastiónové opevnenie), s náznakovou rekonštrukciou zaniknutých brán a ich pril’ahlého územia, s perspektívnym odstránením nevhodnej zástavby. Variovala sa miera náznaku zaniknutých častí mestského opevnenia a miera direktívnosti odstraňovania nevhodnej zástavby v kontakte s mestským opevnením. Materiál bol vypracovaný v urbanistickom merítku ako podklad pre Územný plán zóny. Stanovil rámcovú metódu obnovy v pomerne krátkom čase na základe vizuálneho prieskumu celého urbanistického súboru opevnenia. Realizácia obnovy jednotlivých častí sa bude vykonávat' podl’a požiadaviek mesta či vlastníkov parciel, na ktorých sa časti opevnenia nachádzajú.

Materiál pozostáva z kompletizácie a digitalizácie zamerania existujúcich úsekov mestského opevnenia; jeho typologickej charakteristiky (obr. 1), sumarizácie výsledkov stavebno-historického vývoja (obr. 2-3), hypotetických rekonštrukcií jednotlivých vývojových etáp (obr. 4-6), statického prieskumu (obr. 7), variantných riešení návrhu prezentácie mestského opevnenia (obr. 8-10) a vypracovania regulatívov vybraného variantu obnovy a prezentácie celého urbanistického systému, vrátane pril’ahlého územia s prípadnou zástavbou (obr. 11-12). Bol vypracovaný aj návrh stratégie obnovy s odporúčaniami pre koordinovaný postup komplexnej obnovy. 


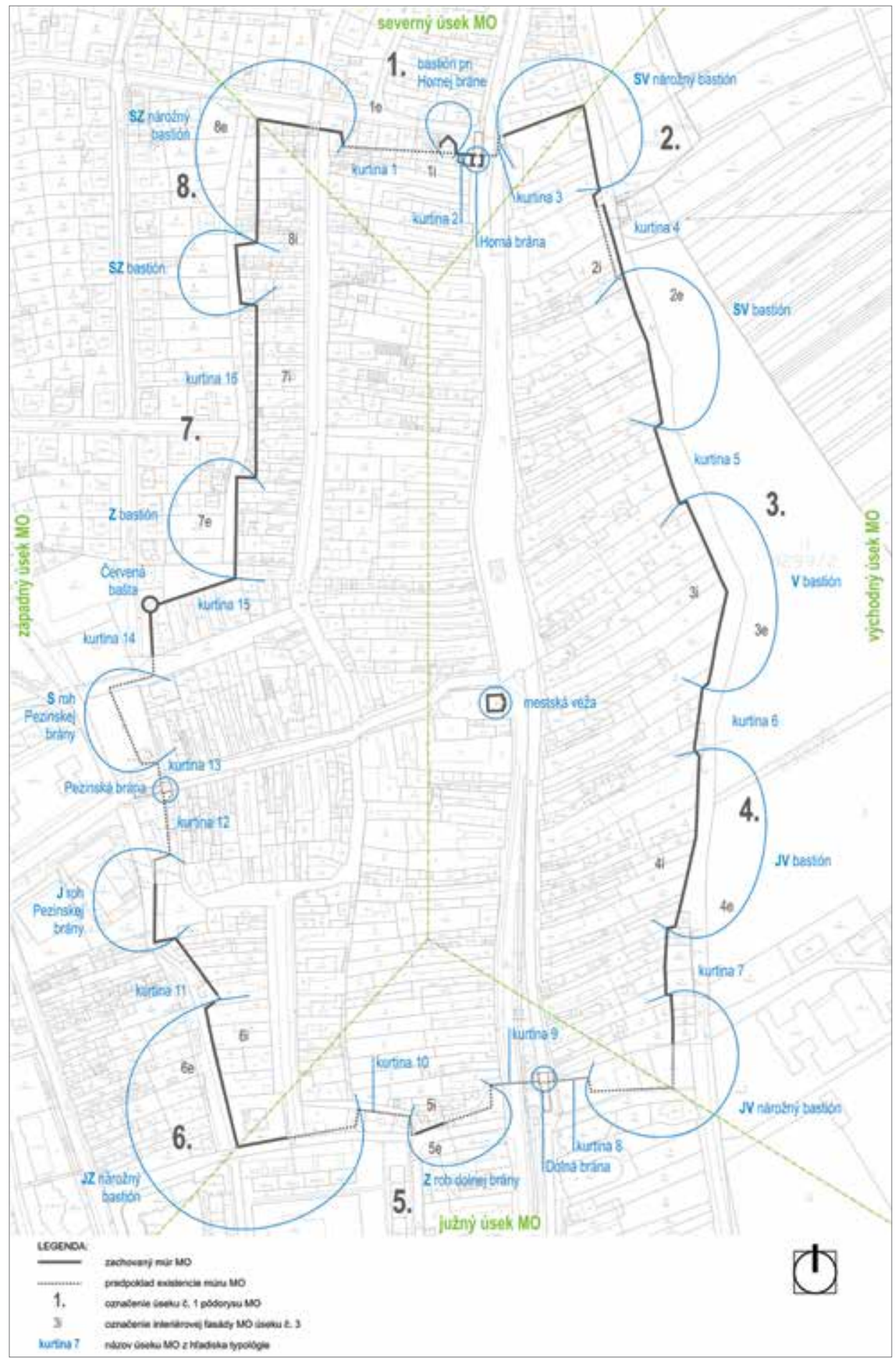

Obr. 1. Schéma typológie mestského opevnenia v Modre. Podl’a Gregorová-Petrášová-Škrinárová 2014.

Abb. 1. Schematische Darstellung der Typologie der Stadtbefestigung in Modra. Nach Gregorová-Petrášová-Škrinárová 2014. 


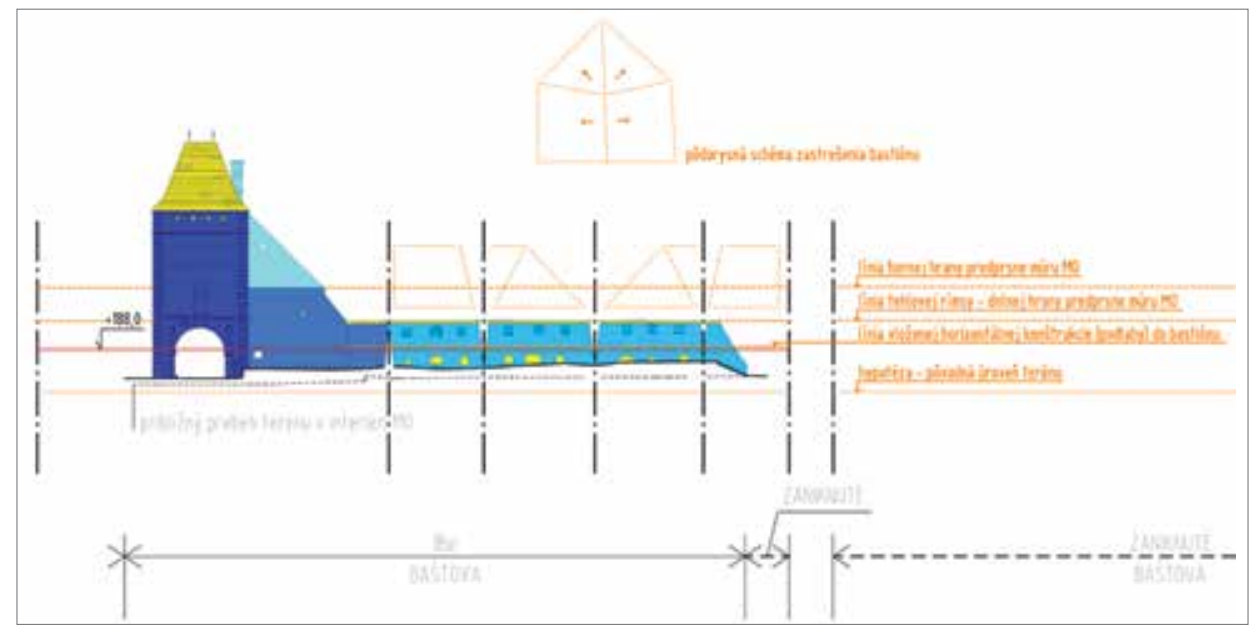

Obr. 2. Sumarizácia poznatkov o stavebnom vývoji mestského opevnenia v Modre (detail lokality Hornej brány) - rozvinutý pohl'ad. Podl'a Gregorová a kol. 2013.

Abb. 2. Zusammenfassende Darstellung der Erkenntnisse über die bauliche Entwicklung der Stadtbefestigung in Modra (Detail der Fundstelle Oberes Tor) - abgewickelte Ansicht. Nach Gregorová et al. 2013.
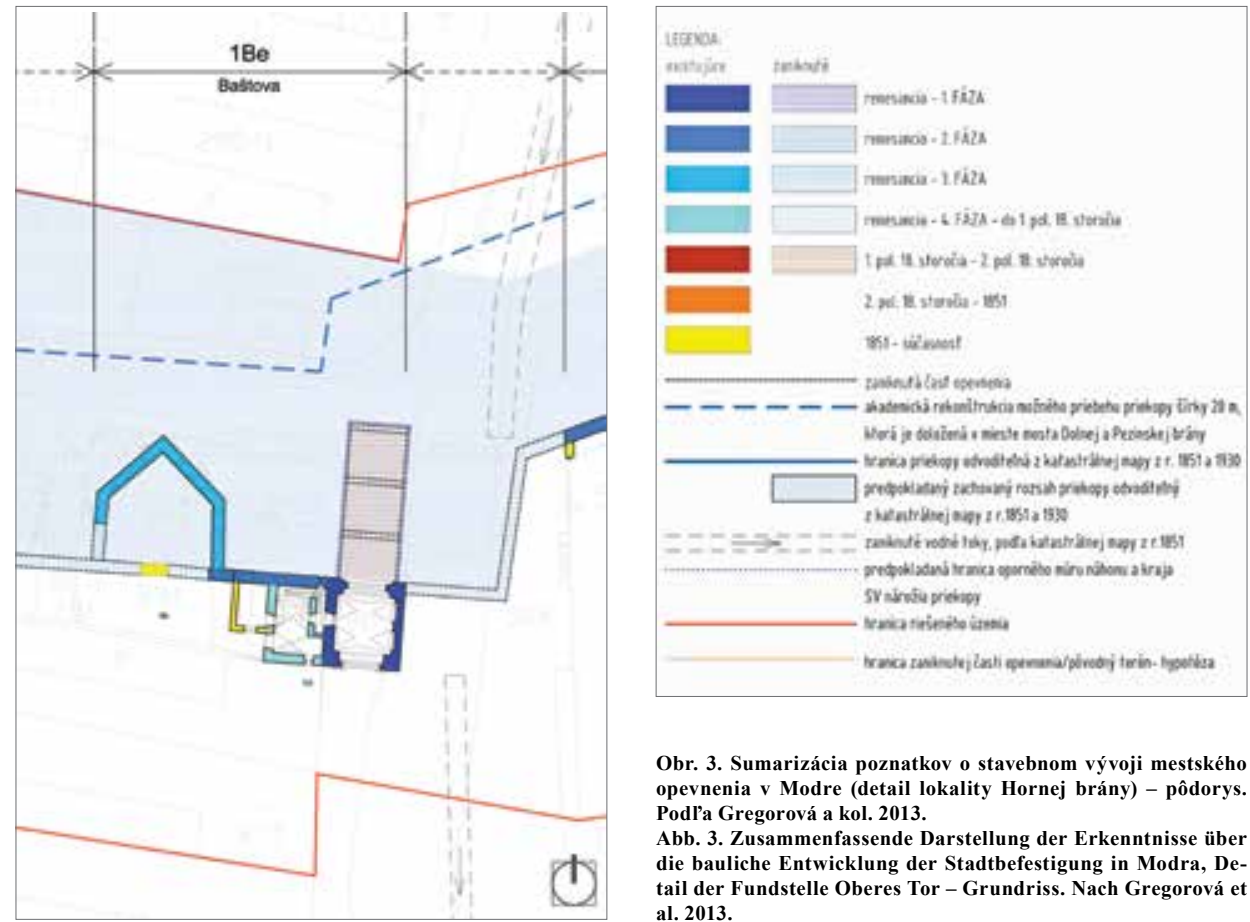

Obr. 3. Sumarizácia poznatkov o stavebnom vývoji mestského opevnenia v Modre (detail lokality Hornej brány) - pôdorys. Podl’a Gregorová a kol. 2013.

Abb. 3. Zusammenfassende Darstellung der Erkenntnisse über die bauliche Entwicklung der Stadtbefestigung in Modra, Detail der Fundstelle Oberes Tor - Grundriss. Nach Gregorová et al. 2013. 

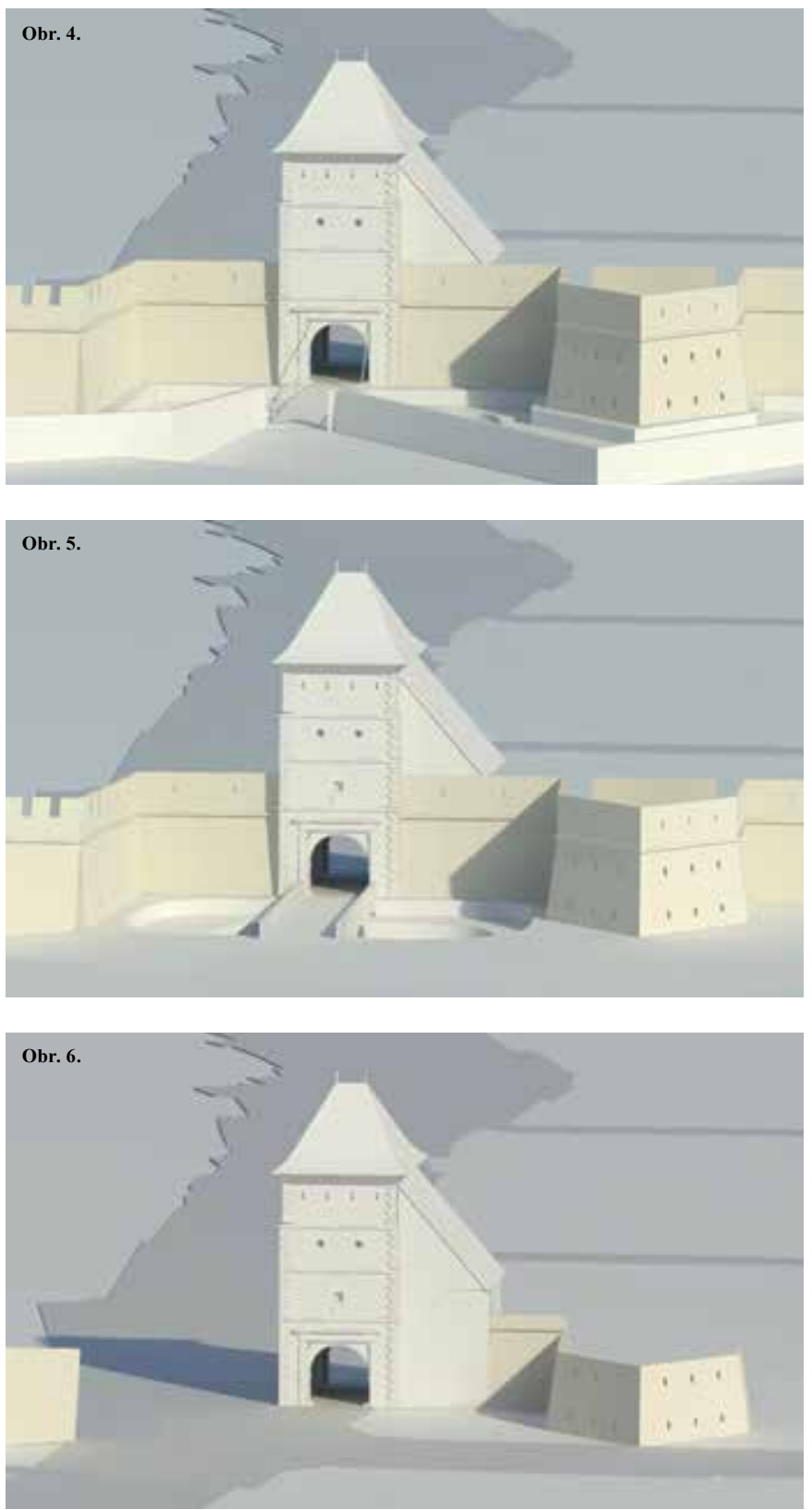

Obr. 4. Hypotetická rekonštrukcia lokality Hornej brány - stav na začiatku 18. storočia. Podl’a Staník-Gregorová a kol. 2014, 19. Vizualizácia S. Petrášová.

Abb. 4. Hypotethische Rekonstruktion der Fundstelle Oberes Tor - Zustand zum Beginn des 18. Jhdts. Nach Staník-Gregorová et al. 2014, 19. Visualisierung S. Petrášová.

Obr. 5. Hypotetická rekonštrukcia lokality Hornej brány - stav v polovici 19. storočia. Podl’a Staník-Gregorová a kol. $2014,21$. Vizualizácia S. Petrášová.

Abb. 5. Hypotethische Rekonstruktion der Fundstelle Oberes Tor - Zustand zur Mitte des 19. Jhdts. Nach Staník-Gregorová et al. 2014, 21. Visualisierung S. Petrášová.

Obr. 6. Hypotetická rekonštrukcia lokality Hornej brány - súčasný stav. Podl’a Staník-Gregorová a kol. 2014, 27. Vizualizácia S. Petrášová.

Abb. 6. Hypotethische Rekonstruktion der Fundstelle Oberes Tor - heutiger Zustand. Nach Staník-Gregorová et al. 2014, 27. Visualisierung S. Petrášová. 


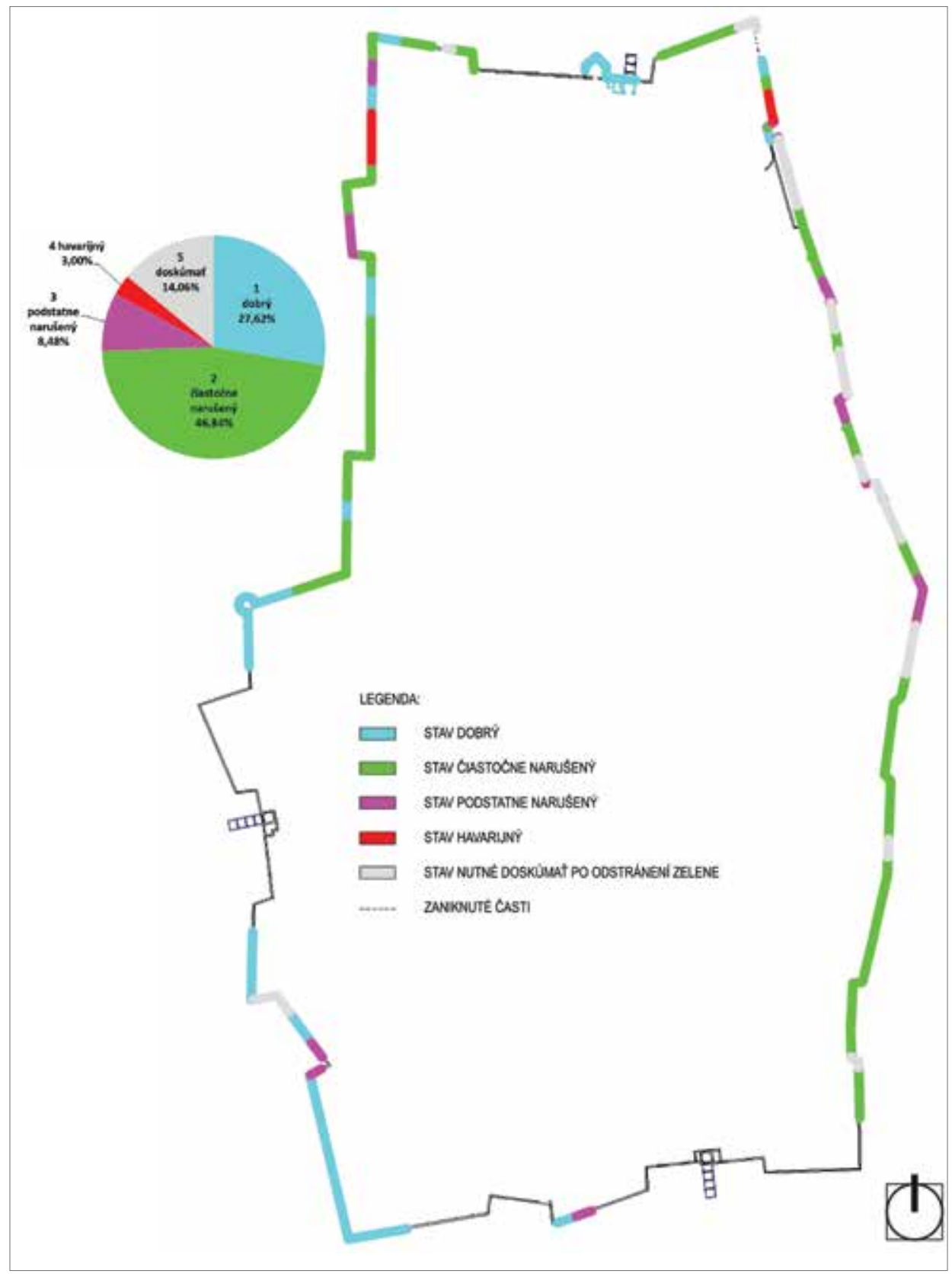

Obr. 7. Vyhodnotenie stavebno-technického stavu mestského opevnenia v Modre - pôdorys a diagram znázorňujúci rozsah poškodenia. Podla Gregorová-Kohút a kol. 2014.

Abb. 7. Auswertung des bautechnischen Zustandes der Stadtbefestigung in Modra - Grundriss und Diagramm veranschaulichen das Ausmaß der Beschädigung. Nach Gregorová-Kohút et al. 2014. 

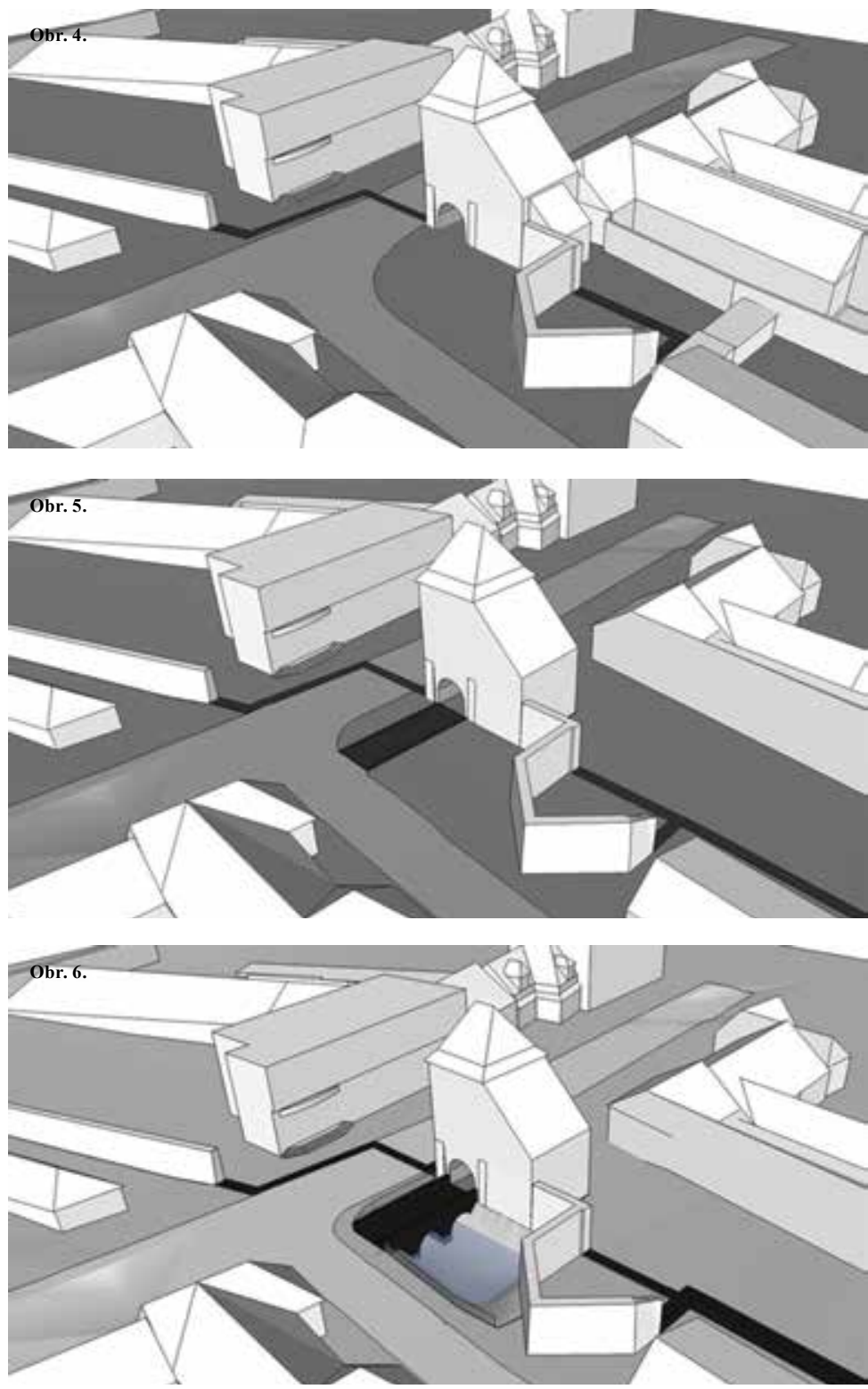

Obr. 8. Variant A prezentácie lokality Hornej Brány v Modre - prezentovanie zaniknutých murív kurtín opevnenia v pôdoryse. Vizualizácia K. Král'ová, Z. Takács.

Abb. 8. Variante A der Präsentation der Fundstelle Oberes Tor in Modra - Präsentation des verschwundenen Mauerwerks der Kurtinen der Befestigung im Grundriss. Visualisierung K. Král'ová, Z. Takács.

Obr. 9. Variant B prezentácie lokality Hornej Brány v Modre - prezentovanie v̌̌etkých predpokladaných častí opevnenia v pôdoryse. Vizualizácia K. Králová, Z. Takács.

Abb. 9. Variante B der Präsentation der Fundstelle Oberes Tor in Modra - Präsentation aller mutmaßlichen Teile der Befestigung im Grundriss. Visualisierung K. Král’ová, Z. Takács.

Obr. 10. Variant C prezentácie lokality Hornej Brány v Modre - prezentovanie zaniknutých murív kurtín opevnenia v pôdoryse a prezentácia mosta a časti priekopy v pôvodnej nivelete (za predpokladu, že sa existencia konštrukcie mosta potvrdí archeologickým výskumom). Vizualizácia K. Král'ová, Z. Takács.

Abb. 10. Variante $C$ der Präsentation der Fundstelle Oberes Tor in Modra - Präsentation des verschwundenen Mauerwerks der Kurtinen der Befestigung im Grundriss und Präsentation der Brücke und eines Grabenteils im ursprünglichen Höhenverlauf, unter der Voraussetzung, dass die Existenz der Brückenkonstruktion durch eine archäologische Grabung bestätigt wird. Visualisierung K. Králová. Z. Takács. 


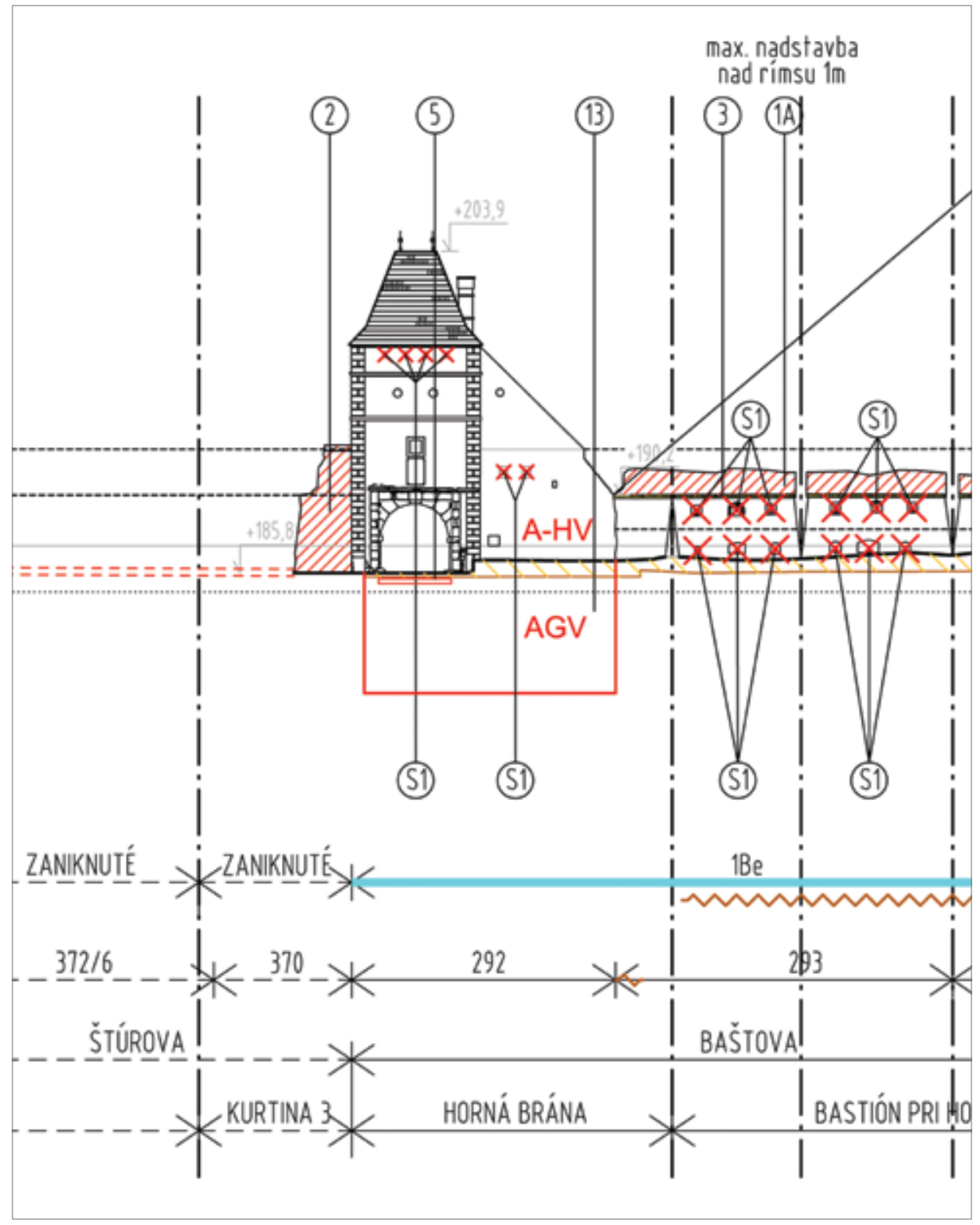

Obr. 11. Regulatívy návrhu prezentácie mestského opevnenia v Modre a jeho pril’ahlej zástavby (detail lokality Hornej brány) - rozvinutý pohl'ad. Podl’a Gregorová-Petrášová-Škrinárová 2014.

Abb. 11. Regulative des Präsentationsentwurfs der Stadtbefestigung in Modra und seiner angrenzenden Bebauung. Detail der Fundstelle Oberes Tor - abgewickelte Ansicht. Nach Gregorová-Petrášová-Škrinárová 2014. 


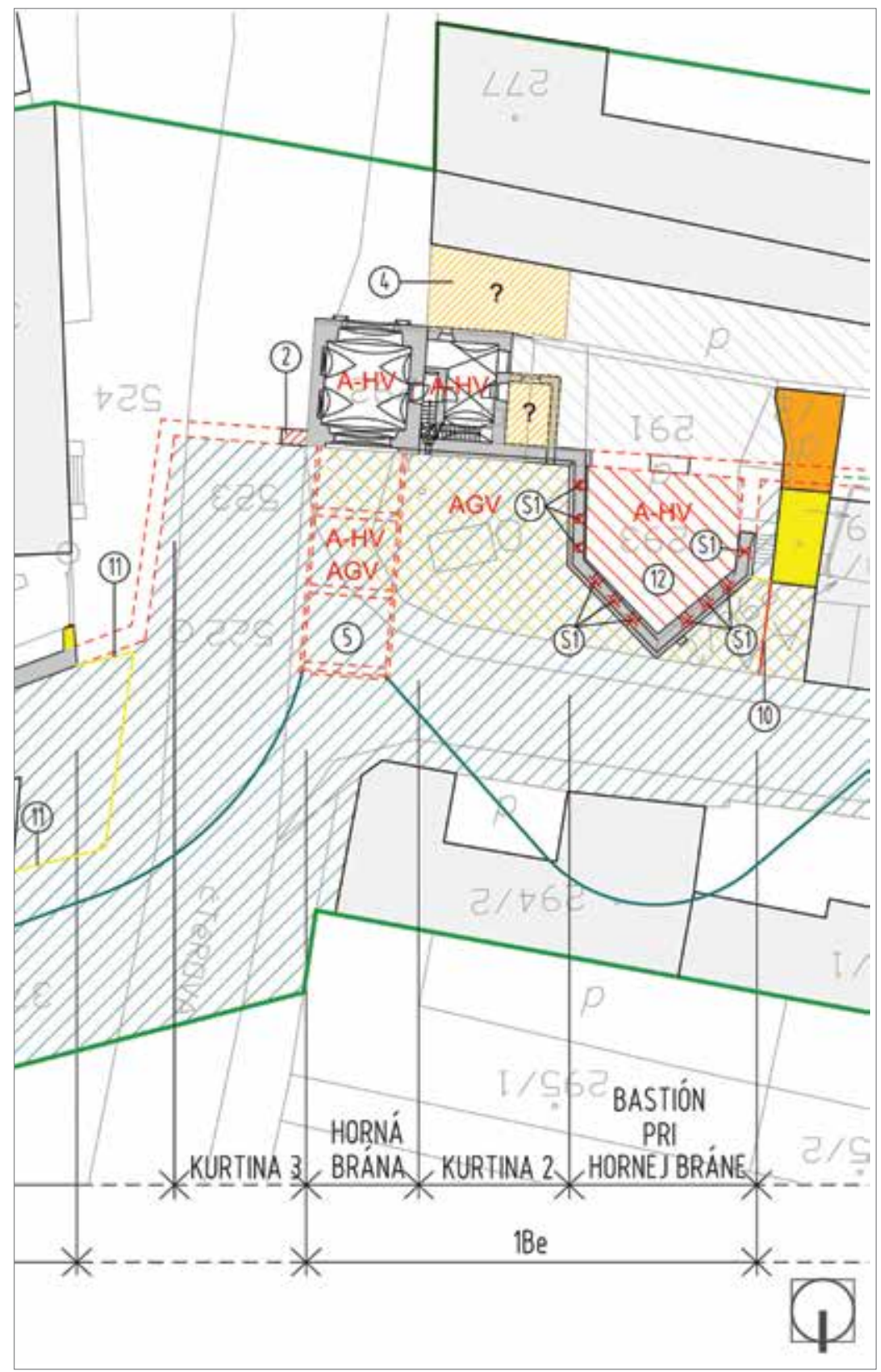

Obr. 12. Regulatívy návrhu prezentácie mestského opevnenia v Modre a jeho prilahlej zástavby (detail lokality Hornej brány) - pôdorys. Podl’a Gregorová-Petrášová-Škrinárová 2014.

Abb. 12. Regulative des Präsentationsentwurfs der Stadtbefestigung in Modra und seiner angrenzenden Bebauung. Detail der Fundstelle Oberes Tor - Grundriss. Nach Gregorová-Petrášová-Škrinárová 2014. 

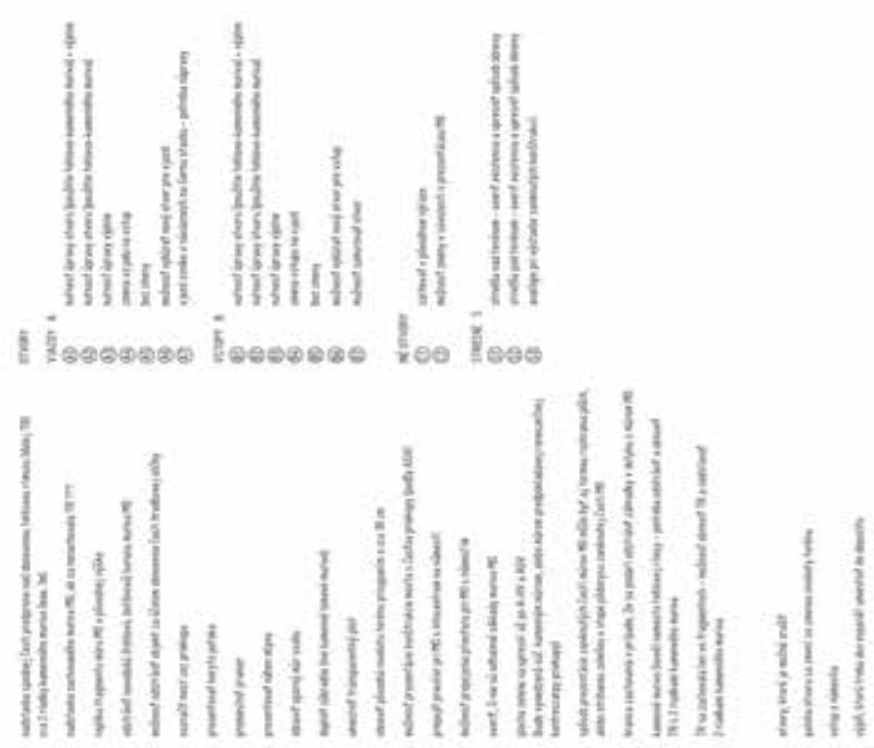

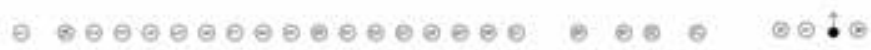

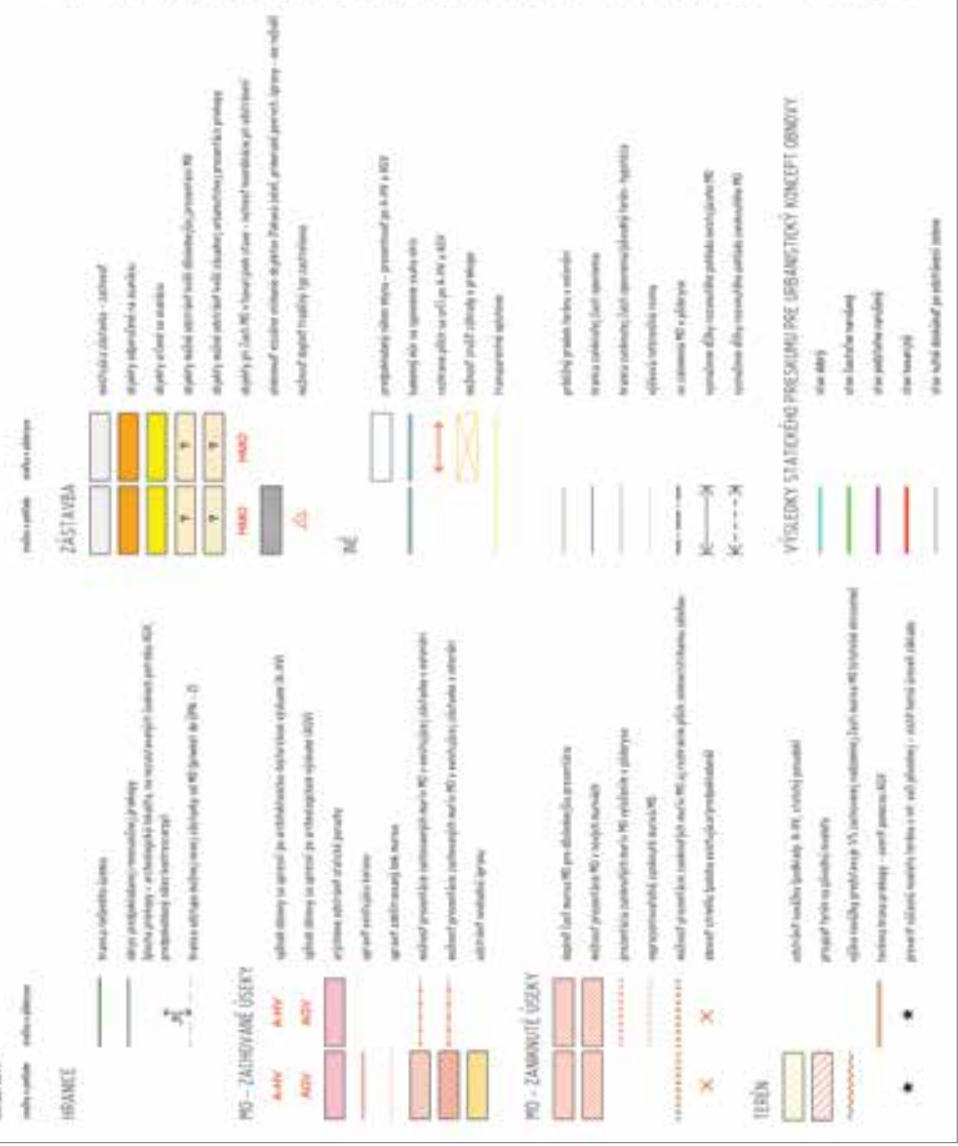


V nasledujúcej časti príspevku budú v krátkosti predstavené doktorandské práce, ktoré sa v súčasnosti spracovávajú a ilustrujú názor na problematiku obnovy torz architektúry z pozície architekta. Budú sa venovat' konštrukciám chrániacim torzá a hodnoteniu a pasportu fortifikačných stavieb na území Slovenska, reprezentovaných hradmi a stredovekými mestskými opevneniami. Nový prínos $\mathrm{v}$ daných problematikách sa očakáva v spracovaní typológie krycích stavieb nad torzami a v novom pohlade na hodnotenie kvality pamiatkovej obnovy opevnení a hradov nielen očami pamiatkara, ale aj architekta ako autora prezentácie pamiatky.

\section{Ochranné konštrukcie a krycie stavby torz architektúry}

Predmetom dizertačnej práce sú ochranné konštrukcie a krycie stavby realizované od vzniku štátnej pamiatkovej starostlivosti po súčasnost' pre ochranu torz rôzneho typologického druhu pôvodných stavieb. Predmet výskumu sa prelína s archeológiou, ruiny a torzá sú však chápané z pohl'adu architekta. Dizertácia sa nezaoberá torzami prezentovanými ex situ a dočasnými krycími stavbami (napr. nad miestami archeologického výskumu). Jej ciel’om je typologické rozdelenie ochranných konštrukcií a krycích stavieb nad torzami, popísanie determinantov vplývajúcich na návrh, ich aplikácia na vybranom torze a zostavenie súboru odporúčaní pre metodika a projektanta pomáhajúcich pri koncipovaní návrhu ochranných konštrukcií a krycích stavieb.

Na základe štúdia literatúry vyplýva táto pracovná verzia terminológie. Ochranná konštrukcia torza je konštrukcia stojaca na torze, zabezpečujúca jeho ochranu pred škodlivými vplyvmi počasia za účelom spomalit' deštruktívne pôsobenie času. Porovnaním s definíciou pojmu ruina môžeme povedat', že účelom takejto konštrukcie je do určitej miery nahradit' zabezpečenie stavby, ktoré v minulosti poskytovali niektoré jej chýbajúce časti (strecha, okná, dvere a pod.). Krycia stavba je stavba plniaca funkciu ochrany torza (podobne ako ochranná konštrukcia), okrem toho ho aj prekrýva. Krycie stavby s uzavretým interiérom chránia pred vonkajšími vplyvmi, navyše je v nich možné nastavit' pre torzo optimálne klimatické podmienky (obr. 13).

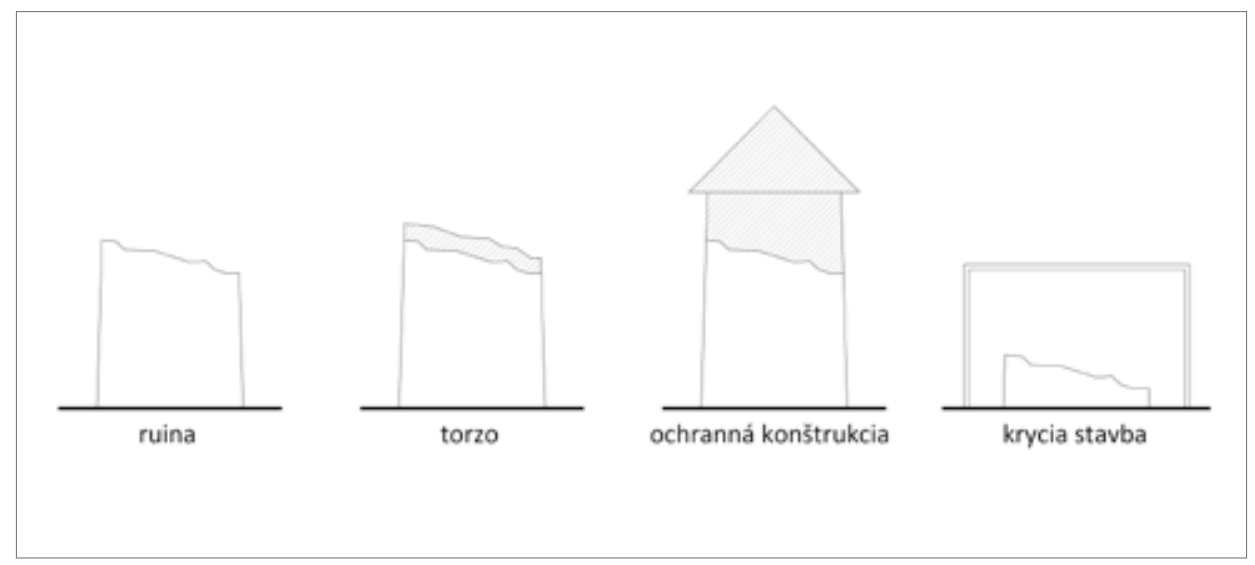

Obr. 13. Schéma znázorňujúca ruinu, torzo, ochrannú konštrukciu a kryciu stavbu. Kresba L. Chovancová.

Abb. 13. Schematische Darstellung einer Ruine, eines Torsos, einer Schutzkonstruktion und eines Überdachungsbaus. Zeichnung L. Chovancová.

Ochranné konštrukcie a krycie stavby sú považované za jeden zo spôsobov konzervácie ruiny (popri samotnej konzervácii a opätovnom zasypaní archeologického náleziska; Ashurst 2007, 147). Prvé prestrešenia ruín boli u nás realizované v polovici 19. storočia (Bóna-Plaček 2007, 50). Spočiatku boli stavané z tradičných konštrukcií. S vývojom doby sa začali používat' najnovšie materiálové a konštrukčné možnosti. Niekedy boli progresívne riešenia na pamiatke 
len skúšané. Dnes sa kvôli morálnej zastaranosti ${ }^{6}$ a kvôli ich technickým poruchám ${ }^{7}$ takéto konštrukcie nahrádzajú. Sú náročným zadaním pre architekta, vyžadujú znalosti tradičných konštrukčných princípov aj možných moderných konštrukčných riešení. Na návrh novej konštrukcie chrániacej originál vplýva viacero determinantov. Architekt pri jej navrhovaní musí mat' na zreteli okrem zachovania fyzickej podstaty pozostatkov architektúry (v našom prípade ruiny) aj ich prípadnú architektonizáciu (vytvorenie torza) a zachovanie vzt’ahu ruiny/torza s prostredím.

Ochranné konštrukcie a krycie stavby môžu prekrývat' archeologickú lokalitu bez zvyškov architektúr (pohrebisko z 11. storočia vedl’a Katedrály sv. Emeráma, Nitriansky hrad), solitérny objekt (Suenov kameň, Morayshire, Škótsko; obr. 14), solitérnu architektúru (král'ovský hrad Koldinghus, Velje, Dánsko; obr. 15) až súbor architektúr (megalitický chrámový komplex Hagar Qim, Malta; obr. 16).

Ochranné konštrukcie a krycie stavby sa používajú:

- nad pamiatkami národného a medzinárodného významu, ${ }^{8}$

- nad najstaršími pamiatkami (rímske a ranokrest’anské stavby a i.),

- nad najohrozenejšími pamiatkami, ktoré majú byt' prezentované in situ (ak je potrebné chránit' architektonické články, omietky, nástenné mal'by alebo iné vzácne či krehké časti nálezu); transfer ruiny sa používa, len pokial' je ohrozená fyzická podstata pamiatky, - ak funkčné využitie archeologickej lokality vyžaduje vytvorenie vnútorného priestoru.

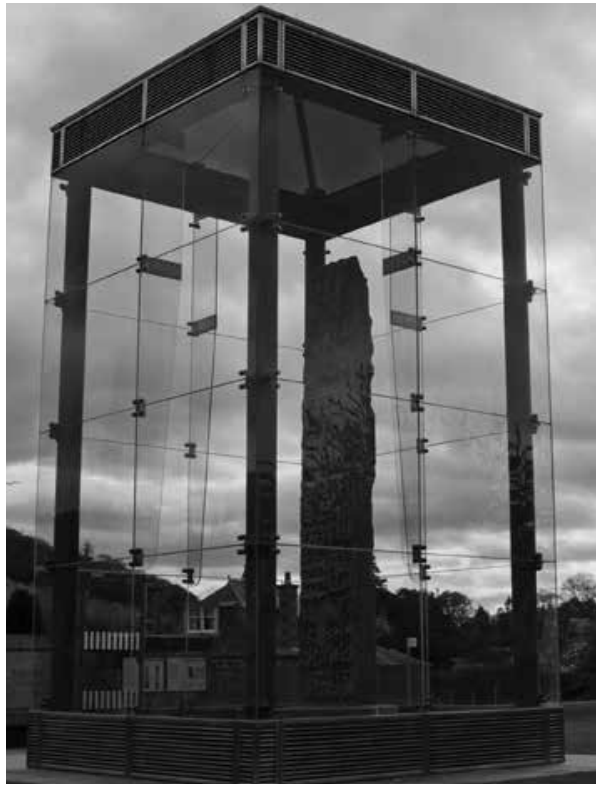

Obr. 14. Krycia stavba solitérneho objektu - opracovaný kameň s reliéfom. Zdroj http://dionysosphotography.blogspot. sk/2011/04/suenos-stone-forres-scotland.html, cit. 20.1. 2015. Abb. 14. Überdachungsbau eines solitären Objekts - mit Reliefsteinen bearbeitet. Entnommen aus http://dionysosphotography.blogspot.sk/2011/04/suenos-stone-forres-scotland.html, abgerufen am 20. Januar 2015.

\section{Metódy pamiatkovej obnovy prostredníctvom ochranných konštrukcií a krycích stavieb nad torzami}

Hlavné determinanty, ktoré vplývajú na návrh ochranných konštrukcií a krycích stavieb torz sú klíma, situovanie $\mathrm{v}$ krajinnom alebo urbanizovanom prostredí a zatažitel'nost' ruiny. Z nich sa odvíja jednotná rámcová pamiatková metóda obnovy a to, či nová konštrukcia bude stát' na murivách alebo mimo torza. Nová konštrukcia môže byt' z hl'adiska metódy obnovy vzhl'adom na prezentáciu zanikajúceho javu koncipovaná ako exaktná, analogická, hypotetická alebo náznaková slohová rekonštrukcia. Pokial' nová konštrukcia nemá ambície byt' reminiscenciou zanikajúceho javu, v takom prípade ide o novotvar, ktorý je bud' kontrastný alebo neutrálny (obr. 17).

Exaktná slohová rekonštrukcia ruín sa používa, pokial' došlo k náhlemu zrúteniu pamiatky a existuje dostatočná dokumentácia na poznanie jej pôvodného tvaru. Príkladom je opätovné postavenie Kampanily sv. Marka v Benátkach po náhlom kolapse konštrukcie. Analogická rekonštrukcia sa používa, ak pre daný prípad existujú typické dobové riešenia.

6 Napríklad prekrytie Ara Pacis, Rím, Taliansko. Prvá krycia stavba od V. B. Morpurga z roku 1938 bola nahradená realizáciou podla návrhu R. Meiera v roku 2005.

7 Napríklad Cassa del Casale, Pizza Armerina, Sicília, Taliansko. Prvá ochranná konštrukcia od Minissiho z roku 1958 bola kvôli technickým poruchám nahradená inou v roku 2008.

8 Prekrývanie ruín národného významu sa v histórii stalo nástrojom budovania národnej identity. V 30 . rokoch 20 . storočia bolo prekryté na podnet Musolliniho Ara Pacis. Oltár bol spomienkou na slávne časy starovekého Ríma. Na území Slovenska bolo v 1931-1933 prekryté pohrebisko z 11. storočia na Nitrianskom hrade. 
Hypotetická rekonštrukcia už v súčasnosti nie je odporúčaná, pracuje s ňou experimentálna archeológia.

Podl’a naznačovanej miery zachovania môže byt' náznaková rekonštrukcia stvárnená ako:

- plocha, napr. v úrovni nášlapnej vrstvy,

- múrik (severná línia Sabinovského mestského opevnenia),

- čast' hmoty (hmota severovýchodnej veže korunovačnej baziliky Székesfehérvár, Mad’arsko),

- celá hmota - rámová konštrukcia (Villa Romana del Casale, Piazza Armerina, Sicília, prekry tie časti kúpel’ov),

- celá hmota - vonkajší obrys stavby (Villa Romana del Casale, Piazza Armerina, Sicília, prekrytie baziliky),

- celá hmota - plný objem (Castelgrande, Bellinzone, Švajčiarsko).

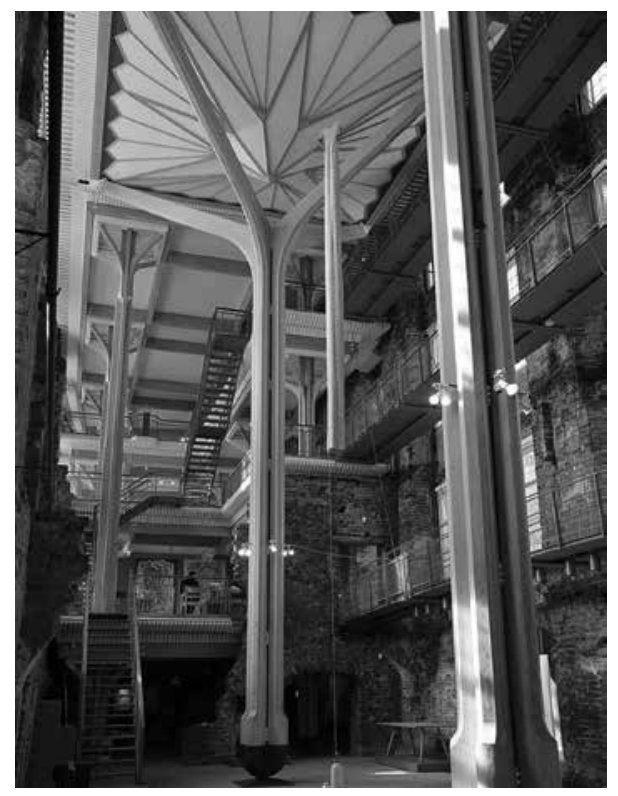

Obr. 15. Ochranná konštrukcia král'ovského hradu vo Velje v Dánsku vo forme výtvarného diela, ktoré je kotvené vnútri torza a nezat’ažuje obvodové múry. Zdroj http://upload.wikimedia. org/wikipedia/commons/thumb/7/73/Koldinghus_-_Old_castle_in_Kolding_-_Denmark_009.jpg/400px-Koldinghus_-_Old_ castle in Kolding - Denmark 009.jpg, cit. 20.1.2015.

Abb. 15. Schutzkonstruktion der Königsburg in Vejle Dänemark in Form einer Plastik, die innerhalb des Torsos verankert ist und die Außenmauer nicht belastet. Entnommen aus http://upload. wikimedia.org/wikipedia/commons/thumb/7/73/Koldinghus_Old_castle_in_Kolding_-_Denmark_009.jpg/400 px-Koldinghus_-_Old_castle_in_Kolding_-_Denmark_009.jpg, abgerufen am $\overline{20}$. Januar 2015 .
Krycie stavby archeologických lokalít sú z metodického hladiska novotvarmi. Takto prekrývané bývajú najvýznamnejšie pamiatky v stave torza, zahŕňajúce vzácne mal'by, mozaiky a pod. V týchto prípadoch sú navrhované tak, aby vytvorili uzatvorený interiér s udržiavanými vlhkostnými a teplotnými podmienkami pre vzácne exponáty (priestory pod nádvorím Bratislavského hradu; Múzeum ranokrest'anského cintorína, Pécs, Mad’arsko).

Moderné (presklené, membránové a i.) konštrukcie ako krycie stavby torz sa na Slovensku navrhujú zriedkavo. V južnom Nemec$\mathrm{ku}$, ktoré má rovnaké klimatické podmienky, ich technicky dobre funguje niekol'ko. Výmena dočasnej krycej stavby nad kostolíkom sv. Jakuba pred Starou tržnicou v Bratislave sa v odborných kruhoch stretáva s nedôverou voči architektonickému stvárneniu prekrytia a zároveň voči jeho technickému riešeniu.

Pri návrhu modernej konštrukcie by architekt mal rátat' s jej odstránením v prípade jej neskoršej morálnej zastaranosti. Nová konštrukcia by vzhl'adom na vývoj architektonických trendov a formovanie názorov v pamiatkovej starostlivosti mala byt' reverzibilná. Ďalšou požiadavkou, ktorá sprístupňuje torzo laickej verejnosti, je primeraná prezentácia a interpretácia pamiatky.

\section{Špecifickost’ úlohy architekta}

Pri zakomponovaní torza s krycou stavbou do okolitého kontextu je potrebná spolupráca s urbanistom (pri urbanizovanom prostredí) alebo krajinným architektom (pri prírodnom prostredí). Ked’že miera zachovania aj miera zasypania ruín je náhodná, architekt má možnost' architektonizovat' ruinu do stavu torza a pracovat's terénom ako objemovo-priestorovým fenoménom, napomáhajúcim zrozumitel'nosti prezentácie zaniknutej časti architektúry. 


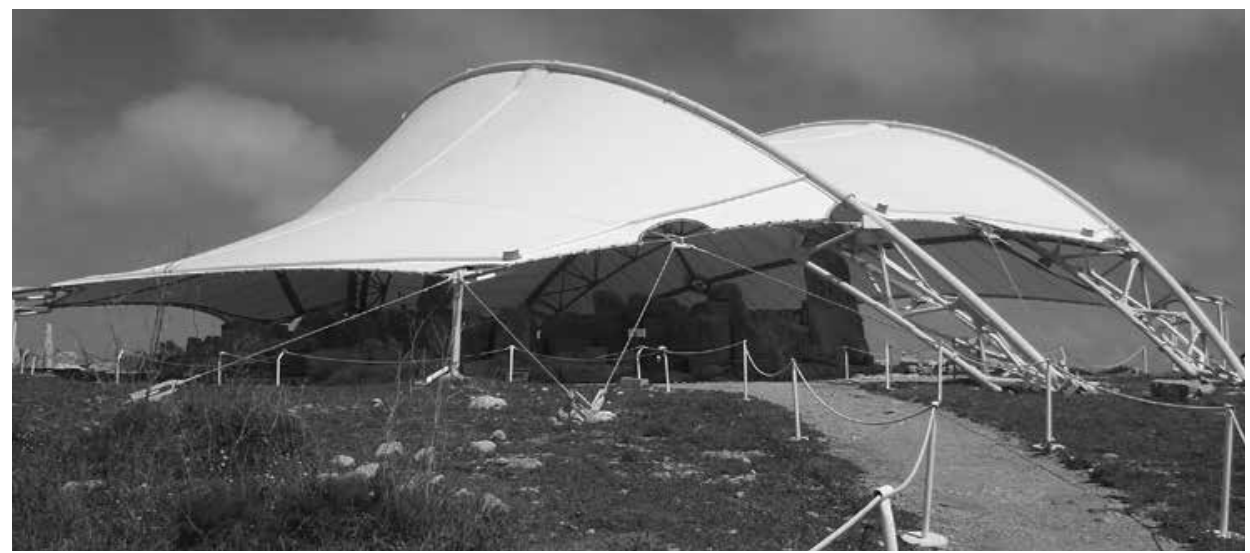

Obr. 16. Krycia stavba nad súborom architektúr - megalitická svätyňa Hagar Qim, Malta. Zdroj http://www.howtomalta.com/2012/04/ hagar-qim-mnajdra-temples.html, cit. 20. 1. 2015.

Abb. 16. Überdachungsbau über einem Architekturensemble - Megalithische Tempel Hagar Qim von Malta. Entnommen aus http://www.howtomalta.com/2012/04/hagar-qim-mnajdra-temples.html, abgerufen am 20. Januar 2015.

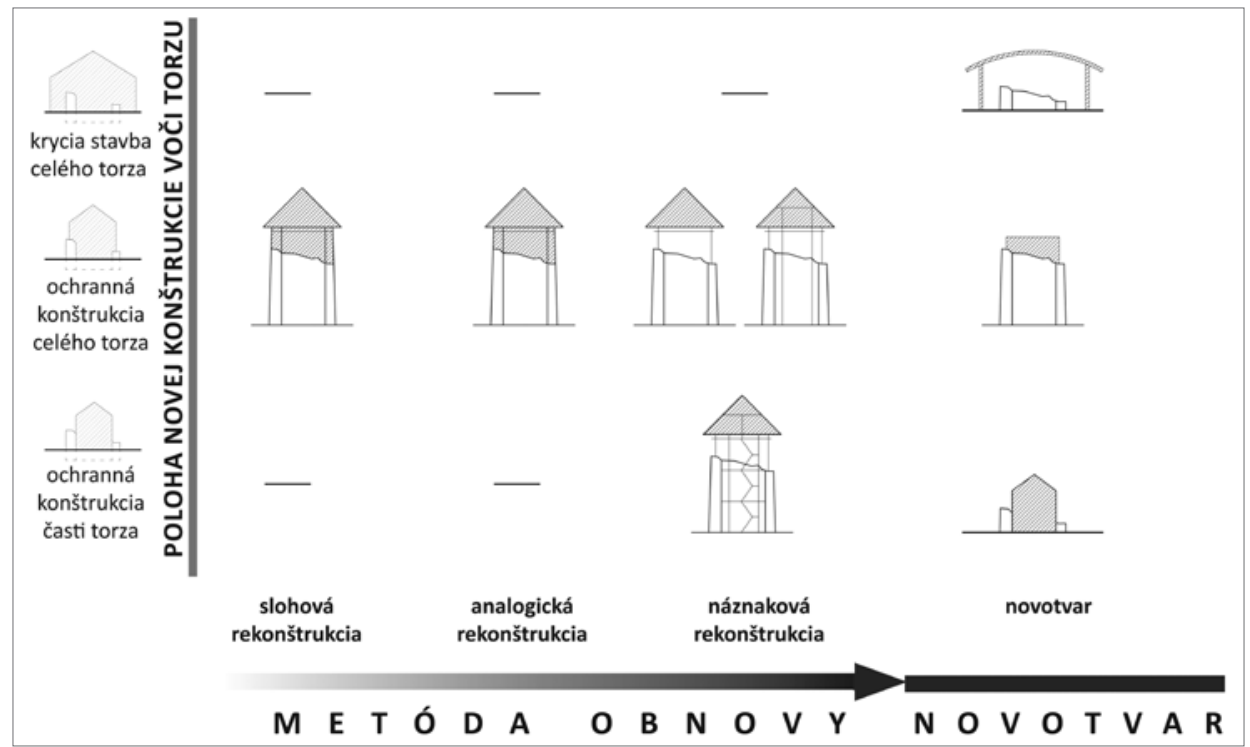

Obr. 17. Spôsoby prezentácie torza ochrannými konštrukciami a krycími stavbami. Schéma L. Chovancová.

Abb. 17. Präsentationsarten eines Torsos mit Schutzkonstruktionen und Überdachungsbauten. Schematische Darstellung L. Chovancová.

V prípade navrhovania ochranných konštrukcií nad torzami rôznymi metodickými prístupmi musí architekt $\mathrm{v}$ úlohe projektanta dobre poznat' znaky pôvodnej stavby. Iba vtedy ju dokáže abstrahovat' (procesom štylizácie alebo transformácie), a tým na zvyškoch architektúry naznačit' $\mathrm{v}$ primeranej miere jej zaniknuté časti. Musí tiež dobre technicky vyriešit' styk originálu a novej konštrukcie. Od architekta sú vyžadované znalosti tradičných konštrukčných princípov (interpretácia tektoniky stavby, návrh ochrannej konštrukcie v tradičnom výraze) a prehlad o možných moderných konštrukčných riešeniach so zretel’om na maximálnu ochranu ruiny. V celom procese navrhovania je dôležitá úzka spolupráca s metodikom.

Pri návrhu krycej stavby má architekt na zreteli ochranu originálu pri komplikovanej priestorovej stratigrafii lokality a počas projektovej prípravy, prípravy staveniska a realizácie ko- 
ordinuje kolektív. Pri návrhu uzatvoreného klimatizovaného priestoru je potrebná spolupráca so vzduchotechnikom, stavebným technológom a stavebným fyzikom, aby boli stanovené také podmienky, ktoré dochované torzo neporušia a čo najviac spomalia proces jeho deštrukcie.

\section{Obnova hradov na území Slovenska}

Od roku 2002 výrazne stúpol počet obnovovaných hradov na Slovensku. Dôvodom tohto nárastu je systematické financovanie obnov Ministerstvom kultúry Slovenskej republiky aj vytvorenie špeciálneho grantového programu pre obnovu torzálnej architektúry. Pôvodne financované obnovy z tohto systému mali za úlohu hradné ruiny očistit' od náletovej zelene a staticky stabilizovat'. Väčšina projektov však má v súčasnosti už ovel’a väčšie ambície ako iba stabilizovat' torzo. Aj toto bol dôvod, pre ktorý bola vypísaná téma zameraná na mapovanie ukončených aj práve prebiehajúcich hradných obnov na území Slovenskej republiky.

Ciel'om dizertačnej práce je vytvorit' metodiku pasportizácie hradných obnov, nájst' ich typických reprezentantov a sledovat' prístup architekta k týmto obnovám v jednotlivých obdobiach. Reprezentanti sú vybraní podl'a použitej metodiky pri ich obnove a determinantov, ktoré vplývali na jej vol’bu. Formou konzultácií s odborníkmi a zberom informácií v teréne aj archívoch sa postupne odkrývajú špecifiká tejto problematiky.

Obnova hradov ako typologického druhu je vel'mi špecifická činnost'. Ked’že prevažná čast' hradov je v ruinálnej podobe a pôvodná funkčná podstata týchto areálov je neobnovitel'ná, výskumníci, metodici a najmä architekti stoja pred zložitou úlohou interpretovania a prezentovania týchto významných monumentov.

Názory na obnovu sa od jej inštitucionalizácie v 19. storočí neustále vyvíjajú. Prvé obnovy hradov na území Slovenska sa udiali už počas 19. storočia, kedy išlo prevažne o romantizujúce prestavby hradov na zámky podla aktuálnych požiadaviek investorov (Pálffyovci - Bojnice, Smolenice). Silným trendom boli tiež úpravy hradov na rodové múzeá a rodové hrobky v hradných kaplnkách. Na prelome storočí sa objavujú prvé konzervácie hradných ruín (Strečno, Filakovo). Od začiatku 20. storočia vidíme na našom území vlny hradných obnov, ktoré sú charakteristické preferovanou metódou obnovy a sú od seba oddelené zmenou tejto metódy alebo útlmom realizácie obnov.

\section{Obnova v 20. rokoch 20. storočia}

Obnova hradov počas prvej Slovenskej republiky je viazaná na slovenskú pamiatkovú starostlivost' predstavovanú Vládnym komisariátom na ochranu pamiatok. Po rozpade Rakúsko-Uhorska sa väzby na Mad’arskú pamiatkovú školu úplne prerušili. Pokračovali adaptácie hradov na rodové múzeá bez metodických usmernení (Lubovniansky hrad a i.) a statické zabezpečenia ruín (Trenčiansky hrad, Hrušov, Beckov, Muráň a i.)

\section{Obnova hradov v 50. rokoch 20. storočia}

Vojnou pozastavená pamiatková aktivita sa opät' rozbehla až v roku 1951 založením Pamiatkového ústavu v Bratislave. Prvým výrazným počinom boli práce na záchranu Bratislavského hradu na začiatku 50. rokov, kde výrazná obnova ruiny metódou rekonštrukcie stredovekej podoby hradu zvít'azila nad modernistickými trendmi novostavieb na hradnom kopci. Táto realizácia odštartovala d’alšie, štátom financované, vel'ké rekonštrukcie hradov (Trenčiansky hrad, Oravský zámok, Spišský hrad, Zvolenský hrad, Starý zámok - Banská Štiavnica, Kežmarok, Smolenice a i.), kde vd’aka rekonštrukciám vznikali priestory určené pre múzeá, galérie a iné štátne inštitúcie. V tejto vlne hradných obnov sa pozornost' sústredila najmä na významné hrady v centrách miest alebo ich tesnej blízkosti. Archeologické nálezy sa spravidla prezentovali náznakom - vyložením pôdorysu nálezu v dlažbe alebo formou kamenných múrikov (Vel'ko- 
moravská bazilika, Kostol sv. Salvátora - Bratislavský hrad; starší sakrálny objekt na nádvorí Zvolenského zámku a i.).

\section{Obnova hradov v 70. rokoch 20. storočia}

Medzi rokmi 1961 a 1970 boli vyhlásené najdôležitejšie objekty za národné kultúrne pamiatky (d’alej len NKP), medzi nimi bolo aj pätnást' hradov. Pokračovali rozbehnuté obnovy a začali aj nové, finančne náročné práce na záchranu d’alších hradov. V tejto vlne hradných obnov prevládal výrazný rekonštrukčný prístup s rôznou mierou rekonštrukcie hradu (Bratislavský hrad, Trenčiansky hrad, Zvolenský hrad, Lubovniansky hrad, Oravský hrad, Krásna Hôrka a i.) a začal sa nový silný trend architektonizovaných ruín (Spišský hrad, Strečno, Devín a i.). Ako doplňujúce metodické prístupy sa uplatňovali výrazné analytické prezentácie starších kultúrnych vrstiev a vnášanie kontrastných novotvarov (Bratislavský hrad, Trenčiansky hrad, Zvolenský hrad; Bóna-Plaček 2007). Prezentácia archeologických nálezov pokračovala v trende z predchádzajúceho obdobia (Vel'komoravský kostol na hrade Devín; Jiskrova pevnôstka - Spišský hrad), ale vznikajú aj nové prístupy, ako napríklad krycia stavba nad starokrest’anským kostolom na Devíne či náznaková rekonštrukcia hospodárskych objektov v celej ich hmote na Spišskom hrade.

\section{Súčasná obnova hradov}

Vlna súčasnej obnovy hradov sa rozbehla po útlme v 90. rokoch až po roku 2002, kedy bol založený Pamiatkový úrad Slovenskej republiky. Odvtedy po súčasnost' sa obnovilo (prípadne sa obnovuje) 46 hradov, z čoho až 32 hradov sa obnovuje konzervačnou metódou. Konzervačný prístup sa objavuje v takejto rozsiahlej miere prvýkrát od vzniku pamiatkovej starostlivosti. V porovnaní s preferenciou metód obnovy od vzniku modernej pamiatkovej starostlivosti (po druhej svetovej vojne) je objem tvorby architektov pri obnovách minimalizovaný. V predchádzajúcich obdobiach dostávali práve architekti široký priestor nielen na novú tvorbu (Bratislavský hrad, Trenčiansky hrad a i.), ale aj náznakové rekonštrukcie zaniknutých skutočností (Trenčiansky hrad, Bzovík, Spišský hrad a i.), analytické prezentácie (Zvolenský zámok, Bratislavský hrad a i.) a architektonizovanie ruín (Devín, Strečno, Spišský hrad a i.).

Protipól vel'kej skupine konzervovaných, autenticky dochovaných hradov tvorí malá, ale významná skupina hradov, na ktorých je používaná rekonštrukčná metóda obnovy s dotváraním originálu výraznými kontrastnými novotvarmi. Tento typ obnovy sa deje výlučne na hradoch, ktoré už v minulosti boli raz alebo aj viacnásobne obnovené, kde je narušená autenticita originálu použitím predchádzajúcich nevhodných technologických postupov. Práve pri tomto type obnov dochádza $\mathrm{k}$ rozsiahlym prezentáciám archeologických nálezov $\mathrm{v}$ interiérových priestoroch (vel'komoravský val v kazemate na Nitrianskom hrade, rímske architektúry v klimatizovaných priestoroch pod nádvorím Bratislavského hradu).

Takto vznikajú na našom území dve extrémne metodické polohy pri obnovách hradov:

- konzervovanie autenticky dochovaných hradov (obnova zatial' neobnoveného hradu),

- rekonštrukcia a dotváranie kontrastnými novotvarmi v minulosti už obnovených hradov (obnova v minulosti už obnoveného hradu).

\section{Konzervácia autenticky dochovaných hradných ruín/torz}

Katalyzátorom rozsiahleho trendu konzervácie hradných ruín na Slovensku bol fenomén dobrovol'níctva. Celosvetový trend „Do it yourself culture“ ovplyvnil aj oblast' obnovy pamiatok, a to formou rôznych občianskych združení a neziskových organizácií, ktoré začali hrady obnovovat'. 
V 90. rokoch vznikajú prvé dobrovol'nícke združenia so zámerom obnovy hradov. Čistia hradné ruiny od náletovej zelene a podnikajú prvé kroky k statickému zabezpečeniu deštruovaných murív. Prvé dva hrady, ktoré na svoje aktivity získali aj finančnú podporu od Ministerstva kultúry, boli Uhrovec a Lietava. Od roku 2011 Ministerstvo kultúry v spolupráci s Ministerstvom sociálnych vecí a rodiny spustili projekt opravy hradov pomocou nezamestnaných. Občianske združenia majú tak možnost' získat' výpomoc nezamestnaných pri menej špecializovaných činnostiach pri obnovách hradov. Aj vd’aka tomuto programu počet obnovovaných hradov na Slovensku neustále stúpa. V prevažnej väčšine prípadov ide o dosial' nedotknuté hrady, na ktorých sa nastavuje od začiatku konzervačná metóda obnovy (Tematín, Považský hrad, Plaveč, Lietava, Zborov, Šarišský hrad, Kapušany a i.).

Konzervácia je však v tomto prípade chápaná ako statická konsolidácia objektov. Konzervačná metóda obnovy hradných ruín má množstvo nesporných výhod. Jednou z nich je zachovanie autenticity materiálu v najvyššej možnej miere. Používanie tradičných postupov a technológií zabezpečí prirodzené pôsobenie nových vstupov do pamiatky a nekonfliktné spolupôsobenie s pôvodnými materiálmi. S prezentovaním originálnej hmotnej substancie je úzko spätá prezentácia hodnoty veku. Zachovanie pôvodnej ruinálnej atmosféry zabezpečuje silnú emocionálnu pôsobivost' objektu na návštevníka. „Záchrana zrúcaniny týmto spôsobom spočiva predovšetkým v zabezpečeni stability ich konštrukcii a zvýšeni odolnosti stavebného materiálu pred koróziou - čo je však neustály a nikdy nekončiaci proces." (Hoferek-Kohút-Makýš 2006, 24)

Podl'a vyššie uvedeného je jasné, že v konzervačnej metóde ide iba o statické zabezpečenie, nie o interpretovanie a prezentovanie pamiatky. Doplńané prvky majú čisto konštrukčný charakter, bez snahy o vysvetlenie ich pôvodného kontextu v pamiatke. Preto pozorovatel' bez dostatočného vzdelania nemôže pochopit’ pôvodný priestorový kontext súboru objektov. Vnímanie ruiny sa obmedzuje na romantický zážitok z chátrajúceho objektu.

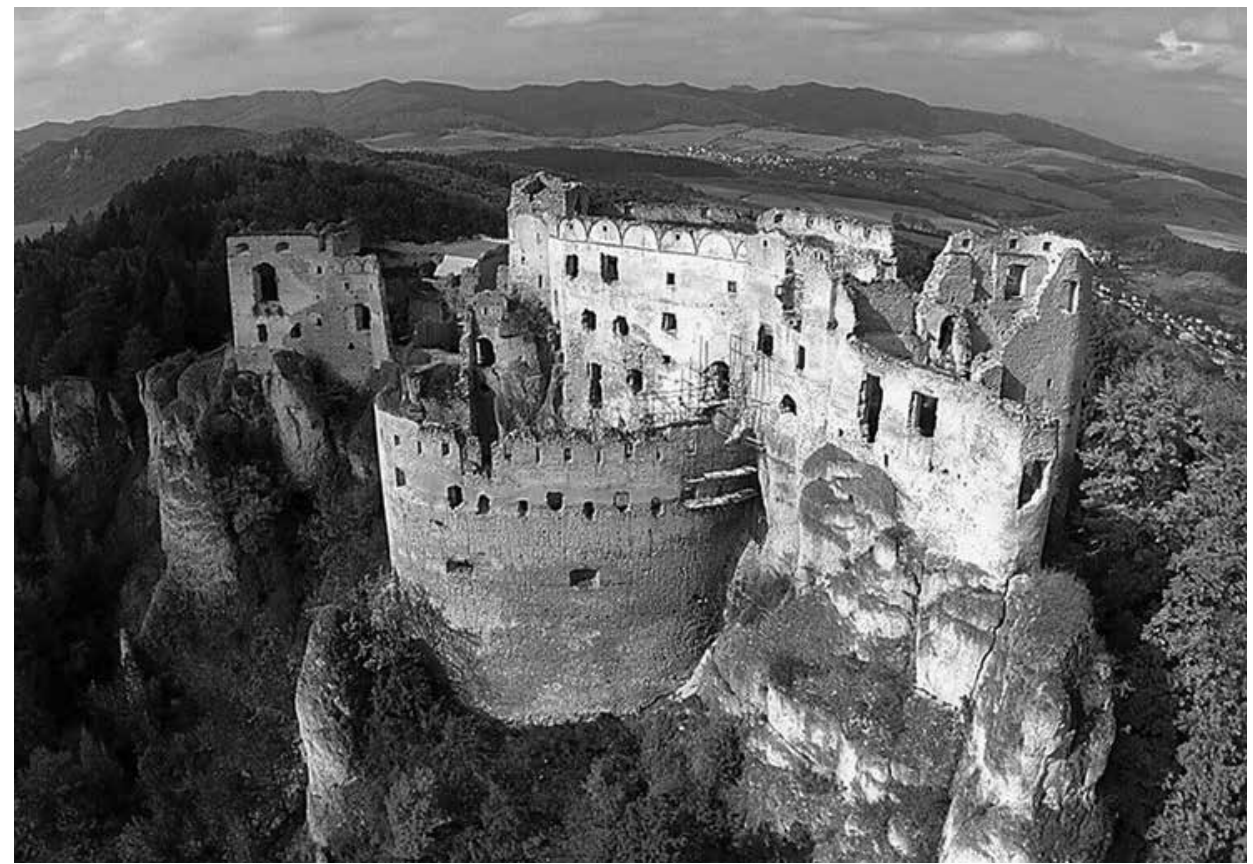

Obr. 18. Letecký pohl'ad na hrad Lietava so skrytou pultovou strechou nad hradnou vežou. Foto M. Hildebrandt. Abb. 18. Vogelperspektive auf Burg Lietava mit versenktem Pultdach auf dem Burgturm. Foto M. Hildebrandt. 


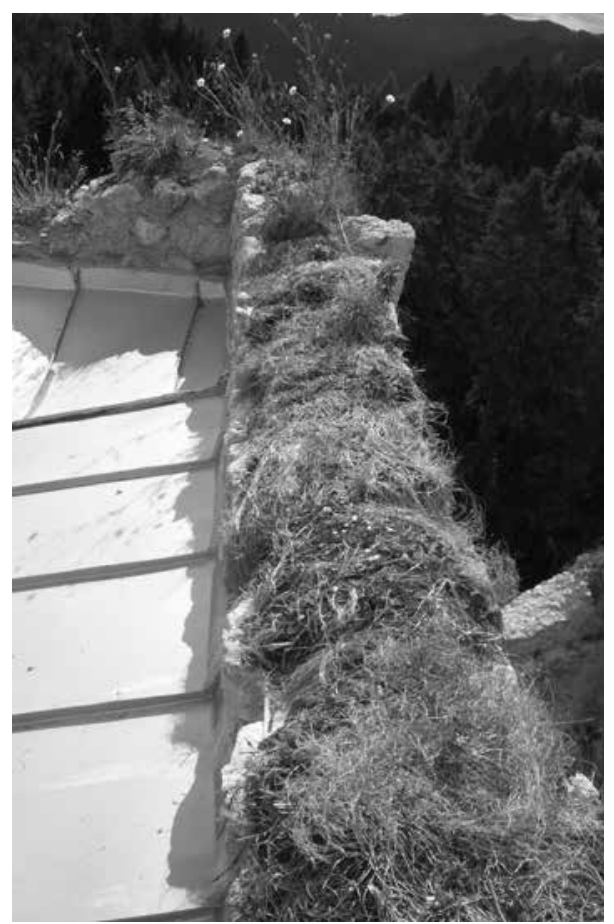

Obr. 19. Styk plochej strechy veže na hrade Lietava s obvodovou stenou, ktorá je ukončená zatrávňovacou korunou. Foto Z. Ondrejková.

Abb. 19. Verbindung des flachen Turmdachs auf Burg Lietava mit der auf der Krone begrünten Wehrmauer. Foto Z. Ondrejková.
Až 27 z takto obnovovaných hradov je realizovaných bez architektonického konceptu. Architekt je v procese obnovy suplovaný metodikom z miestneho KPÚ. V jednotlivých krajoch sa vyprofilovali odborní radcovia (metodici) aj výskumníci špecializovaní na výskum a obnovu hradnej architektúry. To sa ale nedá povedat' o architektoch. Pravdepodobne aj toto bude dôvod, pre ktorý sú architekti z procesu obnovy hradov vo väčšine prípadov vylúčení.

Príkladom obnovy konzervačným prístupom s čiastočnou participáciou architekta (autor čiastkových zásahov na hrade, ale bez konceptu celku) je obnova Lietavského hradu (obr. 18, 19). Združenie na záchranu Lietavského hradu spolupracuje pri jeho konzervácii s odborníkmi. Prebieha tu aplikovaný výskum (testujú sa typy zatrávňovacích korún murív, zloženie malty a i.), ktorého výsledky sú prezentované a používané aj na iných hradných ruinách. Obnova sa sústred’uje najmä na stabilizovanie hradných múrov, vymurovanie kavern, prepadnutých otvorov (okná, portály). Novotvary sa vyskytujú ako dočasné skryté pultové zastrešenia veže starej brány, ktorá dnes slúži ako sklad stavebného náradia a nocl'aháreň pre l'udí obnovujúcich hrad.

\section{Rekonštrukcie a novotvary pri obnovách hradov}

Pri obnovách hradov v minulosti už obnovených sa stretáva metodik aj architekt s metodikou použitou pri predchádzajúcej obnove. Môžu nastat’ nasledujúce situácie vo vzt’ahu k stanovenej (alebo nestanovenej) rámcovej metóde (tab. II):

\begin{tabular}{|c|c|}
\hline \multicolumn{2}{|c|}{ Metodika pri obnove už obnoveného hradu } \\
\hline JE STANOVENÁ RÁMCOVÁ METÓDA OBNOVY & NIE JE STANOVENÁ RÁMCOVÁ METÓDA OBNOVY \\
\hline $\begin{array}{l}\text { nová metóda obnovy sa prispôsobuje } \\
\text { stanovenej rámcovej metóde obnovy }\end{array}$ & \multirow{2}{*}{$\begin{array}{c}\text { nová metóda obnovy pretvorí predchádzajúce zásahy } \\
\text { - vytvorí rámcovú metódu obnovy - } \\
\text { sceli heterogenitu }\end{array}$} \\
\hline \multirow{2}{*}{$\begin{array}{l}\text { nová metóda obnovy mení } \\
\text { stanovenú rámcovú metódu obnovy }\end{array}$} & \\
\hline & \\
\hline \multirow{3}{*}{$\begin{array}{l}\text { nová metóda obnovy nerešpektuje } \\
\text { stanovenú rámcovú metódu obnovy } \\
\text { - nový zásah inou metódou - } \\
\text { vzniká heterogenita }\end{array}$} & \multirow{2}{*}{$\begin{array}{l}\text { nová metóda obnovy odlišná od } \\
\text { predchádzajúcichmetód obnovy } \\
\text { podpori heterogenitu }\end{array}$} \\
\hline & \\
\hline & \\
\hline
\end{tabular}

Tab. II. Vzt’ah rámcovej metódy obnovy z predchádzajúcich obnov hradu a čiastkovej metódy obnovy použitej pri aktuálnej obnove. Zostavila Z. Ondrejková.

Tab. II. Beziehung zwischen der aus vorhergehenden Burgrestaurierungen zugrundegelegten Rahmenmethode der Restaurierung und der bei der aktuellen Restaurierung angewandten partiellen Restaurierungsmethode. Erstellt von Z. Ondrejková. 


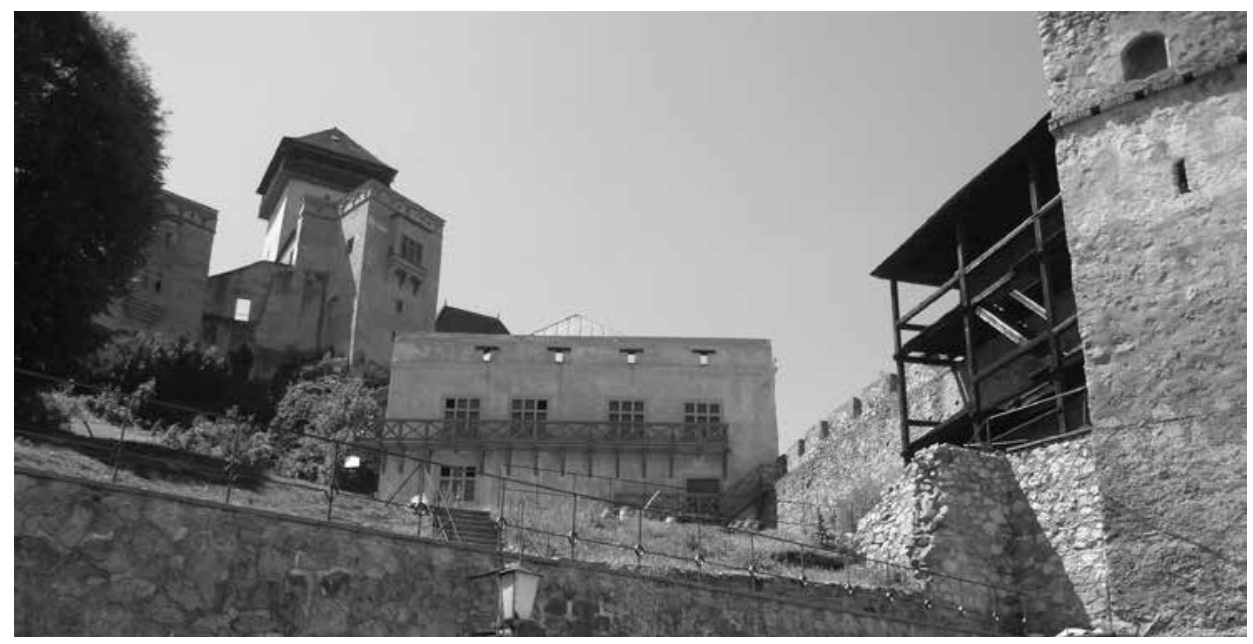

Obr. 20. Rekonštrukcia objektu kasární na Trenčianskom hrade kontinuálne nadväzuje na rámcovú metódu obnovy stanovenú v 50. rokoch. Foto Z. Ondrejková.

Abb. 20. Die Rekonstruktion dieses Kasernenobjekts auf der Trentschiner Burg knüpft kontinuierlich an die in den fünfziger Jahren festgelegten Rahmenmethoden für Restaurierungen an. Foto Z. Ondrejková.

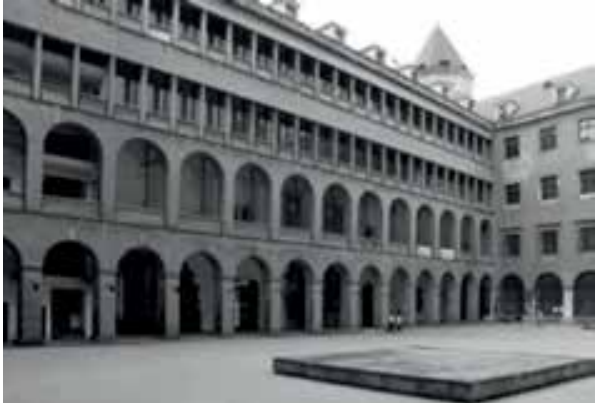

Obr. 21. Novotvar fasády Bratislavského hradu z obnovy v 70. rokoch. Zdroj bratislavskenoviny.sk, cit. 7. 3. 2008.

Abb. 21. Neue Fassadenform der Burg Bratislava von der Restaurierung der Burg in den siebziger Jahren. Entnommen aus bratislavskenoviny.sk, abgerufen am 7. März 2008.

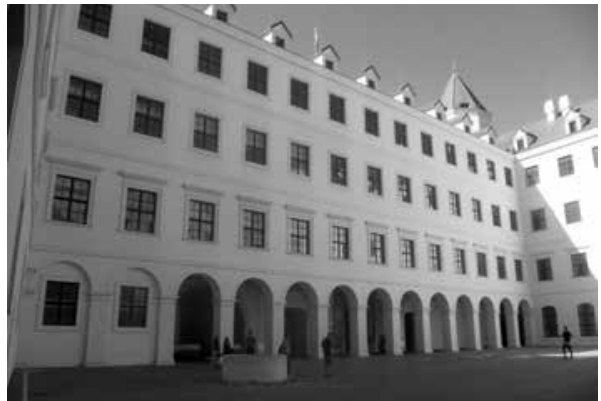

Obr. 22. Scelenie výrazu nádvoria Bratislavského hradu nahradením novotvaru fasády rekonštrukciou barokovej fasády. Foto Z. Ondrejková.

Abb. 22. Einheitliche Ausdrucksgestaltung des Hofes der Burg Bratislava, indem die neue Fassadenform durch eine rekonstruierte Barockfassade ersetzt wurde. Foto Z. Ondrejková.

- Predchádzajúca obnova mala stanovenú rámcovú metódu (d’alej len RM) na areál hradu a táto bola dôsledne dodržovaná. V takom prípade môže nová obnova rešpektovat' pôvodnú metodiku, ako je to v prípade obnovy objektu kasární na Trenčianskom hrade (obr. 20). Trenčiansky hrad je typickým reprezentantom stanovenej rámcovej metódy obnovy, ktorá sa dlhodobo kontinuálne napĺňa. Najnovším zásahom na hrade je rekonštrukcia ruiny objektu kasární. Pri tejto metóde obnovy sa využili konzervačné práce, vedecké rekonštrukcie a kontextuálne novotvary v polohách, kde neboli výskumami zistené pôvodné tvary prvkov (interiérové nosné prvky, schodisko, strecha).

- Predchádzajúca obnova mala stanovenú rámcovú metódu obnovy a zásahy súčasnej obnovy ju pretvárajú. Takýmto príkladom je posledná obnova Bratislavského hradu, kedy sa prezentácia hradu v jeho pevnostnom charaktere premenila na prezentáciu barokového-tereziánskeho zámku (obr. 21-22). Analytické prezentácie starších nálezov sú doplňované novotvarmi nových betónových a presklených prvkov.

- Nová metóda obnovy nerešpektuje pôvodne stanovenú rámcovú metódu a nový (spravidla čiastkový zásah) realizuje odlišnou metódou. Pri takomto prístupe vzniká výrazná heterogenita 


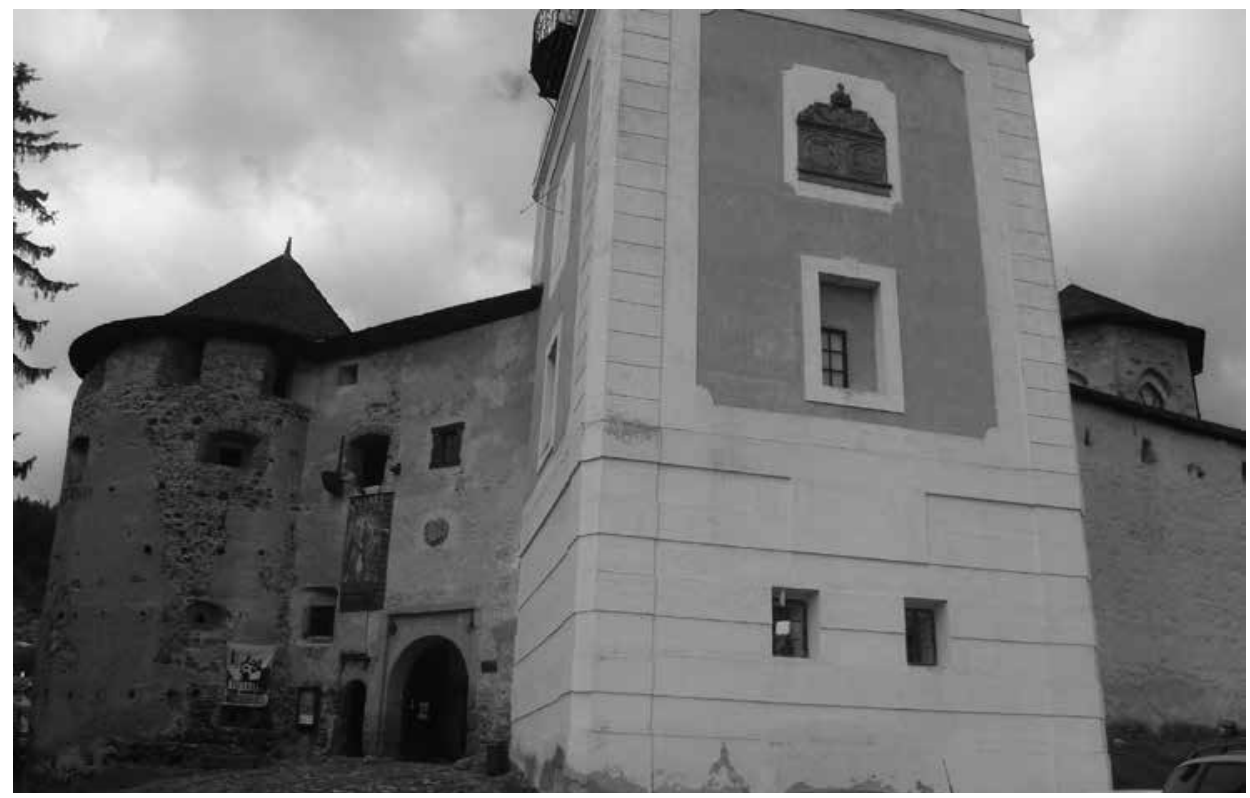

Obr. 23. Rôzny spôsob prezentovania hradieb okolo Starého zámku v Banskej Štiavnici. Lavá strana od veže je konzervovaná s originálnou omietkou, pravá strana rekonštruovaná s novou omietkou. Foto Z. Ondrejková.

Abb. 23. Verschiedene Präsentationsarten der Wehrmauern des Alten Schlosses in Banská Štiavnica. Die linke Seite des Turms wurde mit Originalputz konserviert, die rechte Seite mit neuem Putz rekonstruiert. Foto Z. Ondrejková.

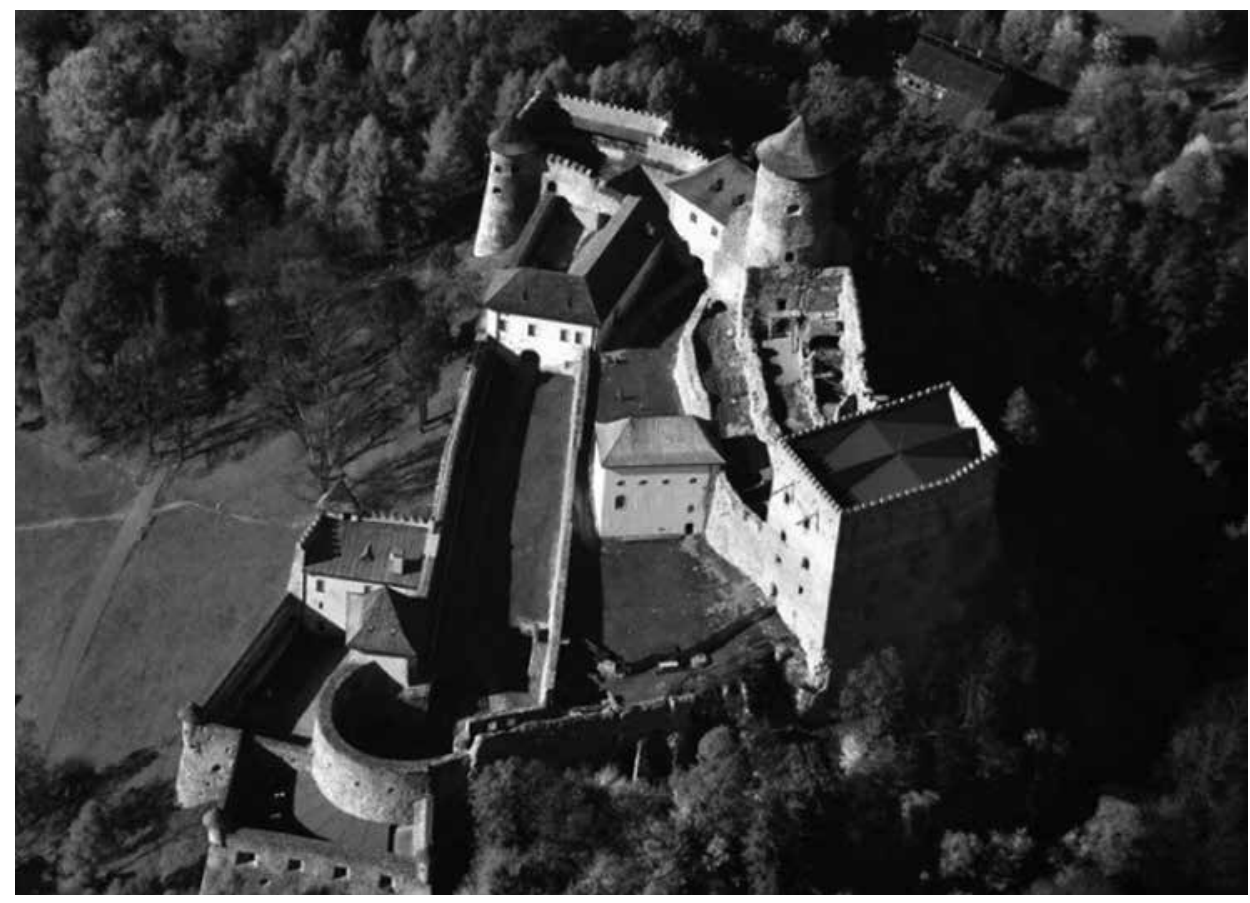

Obr. 24. Areál hradu Lubovňa s rekonštruovanými a konzervovanými objektmi. Zdroj www.staralubovna.sk/galeria-detail/leteckezabery-na -lubovniansky-hrad/, 24. 11. 2014.

Abb. 24. Areal der Burg Lublau mit rekonstruierten und konservierten Objekten. Entnommen aus www.staralubovna.sk/galeria-detail/letecke-zabery-na -lubovniansky-hrad/, aufgerufen am 24. November 2014. 


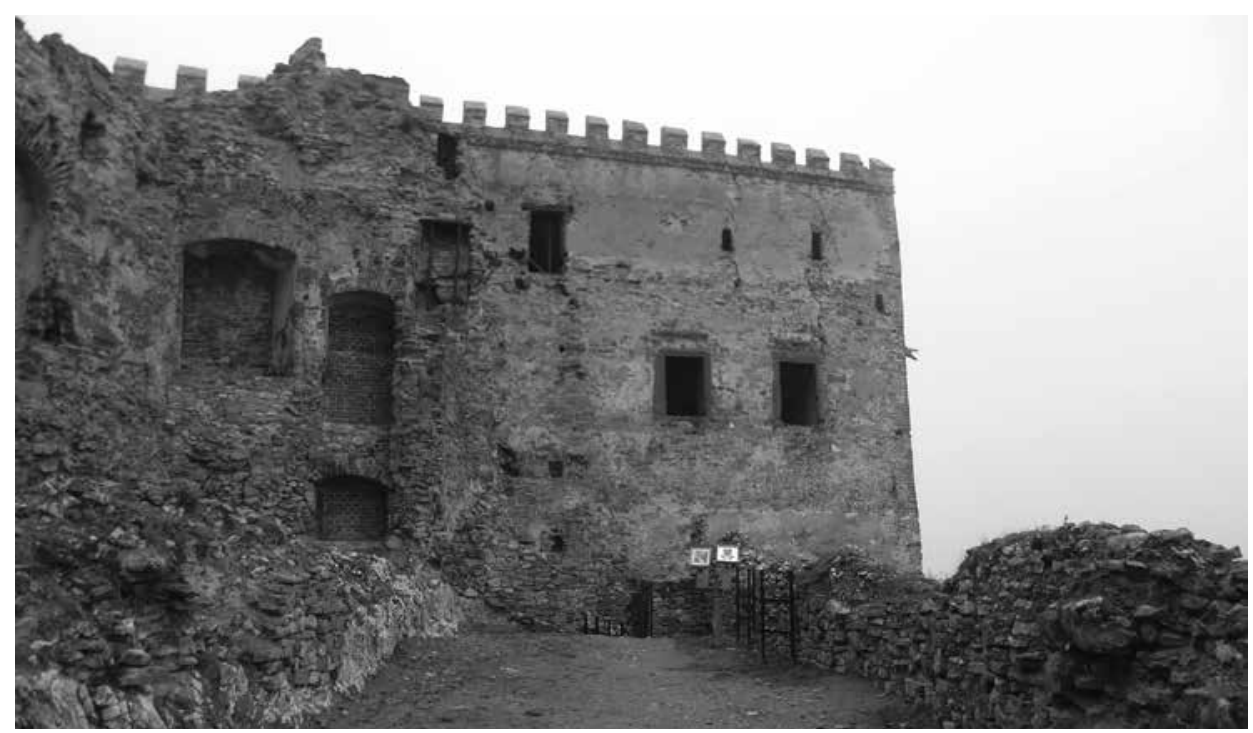

Obr. 25. Konzervované paláce hradu L’ubovňa - nal'avo gotický palác, v strede renesančný palác. Foto Z. Ondrejková. Abb. 25. Konservierte Palasse der Burg Lublau - links gotischer Palast, in der Mitte Renaissancepalast. Foto Z. Ondrejková.

hradného areálu a hrad prezentuje vývoj názorov na obnovu pamiatok, nie svoj vývoj. Takto heterogénny areál je potom vel'mi náročné scelit' (časovo, finančne aj metodicky). Príkladom je banskoštiavnický Starý zámok (obr. 23). Na začiatku 20. storočia bol konzervačnou metódou obnovovaný Kolomanom Luxom. V 60. rokoch začala rozsiahla obnova hradu rekonštrukčnou metódou, ktorou však nebol obnovený celý hrad. Na začiatku 21. storočia sa posledná obnova priklonila k Luxovej metodike. Je tu však dodnes čitatel'ný rozpor v prezentácii areálu.

- Pri obnove hradu nebola stanovená rámcová metóda obnovy. Vtedy rastie riziko nekompatibility nových metodických prístupov s pôvodnými. Príkladom je Lubovniansky hrad, kde sa v jednom areáli stretávajú adaptácia barokového objektu na rodové múzeum Zámoyských z 30. rokov, rekonštrukcia spodného a stredného hradu zo 70. rokov s aktuálnymi konzervačnými postupmi pri objektoch horného hradu, doplnenými náznakovými rekonštrukciami zaniknutých horizontálnych konštrukcií (obr. 24, 25).

\section{Špecifickost’ úlohy architekta}

Architekt je pri spomenutých prípadoch obnov využívaný najmä na tvorbu novotvarov a riešenie novovzniknutých situácií vyžadovaných novým funkčným riešením či prezentáciou odkrytých starších kultúrnych vrstiev, spravidla s rozdielnou stratigrafiou. Do celkového konceptu prezentácie areálu zasahuje len minimálne. Pravdepodobne aj preto vzniká rôznorodá prezentácia hradných areálov. Pamiatkari a výskumníci namodelujú konzervovanie, reštaurovanie či rekonštruovanie originálu a architekt vytvorí nový funkčne či prevádzkovo potrebný prvok. Vo vzt’ahu k originálu sa často uplatňujú novotvary ako dôsledok použitia analytických sond starších kultúrnych vrstiev, $\mathrm{v}$ rámci ktorých sa $\mathrm{z}$ bezpečnostného, prevádzkového alebo prezentačného hl'adiska navrhujú zábradlia, vertikálne komunikácie, prezentácie pôvodných niveliet a i.

\section{Obnova stredovekých mestských opevnení na území Slovenska}

Predmetom doktorandského výskumu tohto druhu torzálnej architektúry je ich pamiatková obnova. Nakol'ko však danej problematike na území Slovenska nebola venovaná pozor- 
nost', systematicky bolo potrebné zosumarizovat' dostupné poznatky. Sú spracúvané do podoby katalógu (pasportu) zachovaných stredovekých murovaných mestských opevnení ${ }^{9}$ a ich obnov, najmä v podobe grafických schém. Zdrojmi poznatkov sú publikované príspevky k danej téme, materiály Pamiatkového úradu SR (zásady ochrany pamiatkových území, rôzne výskumy a i.) a prieskum v teréne. Významným prínosom sú najmä konzultácie s odbornými pracovníkmi KPÚ. Vd’aka ich usmerneniam vzniká materiál prekrývajúci profesie metodika-pamiatkara a architekta.

Stredoveké mestské opevnenia sú súbory stavieb a úpravy pril’ahlých plôch, ktorých hlavnou úlohou je najmä ochrana a obrana mesta, prípadne jeho prilahlých častí, pred nepriatelom. Boli budované najmä v dobe používania chladných zbraní. V súčasnosti tvoria významnú zložku torzálnej architektúry. Na rozdiel napríklad od väčšiny hradov (nachádzajúcich sa v prírodnom prostredí) sú súčastou urbanizovaných štruktúr, bud' v rámci zastabilizovaného historického jadra mesta, alebo v dotyku s dynamicky sa rozvíjajúcimi čast'ami nového sídla. Ich poloha zásadne ovplyvňuje aj požiadavky na ich stvárnenie a funkčné využitie.

Mestské opevnenia svoju pôvodnú funkciu stratili po Satmárskom mieri v roku 1711. Od polovice 18. storočia preto dochádzalo $\mathrm{k}$ ich funkčnej degradácii a mnohé ich prvky sa postupne dostávali do stavu ruiny. Murované prvky boli búrané, pretože prekážali rozrastajúcim sa mestám a novej dopravnej situácii. Ich materiál bol využívaný pri novej výstavbe, prípadne boli sekundárne využívané celé konštrukcie. Pôvodne nezastavané plochy mestských opevnení (parkány, priekopy, hradbové uličky a i.) boli zastavované. Nové objekty vznikali v rozsahu pôvodných parciel alebo najmä v neskoršom období vznikala monobloková architektúra nerešpektujúca pôvodnú parceláciu. Vo väčšine prípadov sa upravovala profilácia terénnych úprav opevnení, zasýpali sa priekopy a rušili sa zemné násypy a valy. Po uvedomení si ich spoločenskej hodnoty sa proces degradácie výrazne spomalil. V súčasnosti sa opevnenia nachádzajú v rôznej miere zachovania, niektoré zanikli úplne. Ked’že sa jedná o komplexy pomerne vel’kého rozsahu, ich mieru zachovania je možné sledovat' v polohe urbanistickej (miera zachovania prstencov a plôch opevnenia) a tiež v polohe architektonickej (miera zachovania jednotlivých prvkov a objektov opevnenia).

\section{Vývoj prístupov k obnove mestských opevnení}

Pamiatková starostlivost' sa začína opevneniam venovat' až po druhej svetovej vojne. Prvú vlnu obnov mestských opevnení môžeme sledovat' približne od 50. rokov 20. storočia. Obnovované a prezentované boli najmä najhodnotnejšie prvky opevnení. Prvoradou nebola ich prezentácia v kontexte celého obranného komplexu. Vo viacerých prípadoch neboli vopred realizované potrebné výskumy a pri samotnej obnove sa používali technológie, ktoré sa neskôr ukázali ako nevhodné. Medzi preferované metódy patrila rekonštrukcia. Zaniknuté prvky boli väčšinou doṕ́ňané analogicky. Obnovu objektov sprevádzala reštitúcia plôch opevnení, bola búraná zástavba v priestoroch hradobných uličiek, parkánov a priekop (Bardejov, Levoča a i.). Výskumy sa v tomto období zameriavali na ucelene zachované úseky alebo jednotlivé solitérne zachované objekty.

Postupne môžeme vnímat' zmenu prístupu k obnove opevnení a približne od 80.-90. rokov 20. storočia môžeme hovorit' o druhej vlne obnov. Dochádza k snahe prezentovat' opevnenia ako urbanistické súbory. Pamiatkové výskumy vznikajúce v tomto období sa často venujú opevneniu ako celku (Trnava, Bardejov, Sabinov). Nad terénom nezachované prvky opevnenia sú skúmané archeologicky, čo podstatne zlepšuje stav ich poznania. Viaceré mestá majú vypracované urbanistické koncepcie obnovy historických jadier a Trnava ako prvá mala samostatný materiál aj pre mestské opevnenie. Vopred pripravené koncepcie aj napriek časovému odstupu umožňujú do-

9 Za stredoveké opevnenia považujeme tie, ktoré takto označuje aj odborná verejnost'. Prípadmi, pri ktorých interpretácii sa názory odborníkov rozchádzajú, sa výskum nevenuje. Nekladie si za ciel' rozšírit' zoznam stredovekých opevnení, ale sumarizovat' poznanie o tých, ktoré už sú vyhlásené za NKP. Na základe konzultácií s Ing. arch. A. Fialom a Ing. arch. I. Staníkom (KPÚ Bratislava) boli ako predmet výskumu vybraté opevnenia v týchto mestách: Bratislava, Trnava, Skalica, Trenčín, Kremnica, Prešov, Bardejov, Sabinov, Podolínec, Kežmarok, Levoča a Košice. 
držat' určenú rámcovú metódu pamiatkovej obnovy, ktorej výsledkom je zjednotenie komplexu opevnenia a zlepšenie jeho čitatel’nosti. Výraznejšie sa preferujú konzervačné metódy. Dôsledne sa uplatňujú na objektoch, ktoré ešte neboli obnovované a teda sa nachádzajú v autentickej podobe. Rekonštrukcia je častejšie používaná pri korekcii nevhodných zásahov realizovaných v prvej vlne obnov. Vzhl'adom na skutočnost', že sa jedná o fragmenty pôvodne ucelenej líniovej stavby, využívajú sa rôzne druhy náznakov zaniknutých častí. Náznaky sa využívajú pri murovaných častiach, ako aj v predpolí opevnenia.

\section{Metódy obnovy mestských opevnení}

Metódy obnovy a prezentácie je možné rozdelit' na prístupy používané na prvkoch opevnení nad terénom zachovaných, prvkov nad terénom nezachovaných a metódy používané na bývalých plochách opevnení.

\section{Metódy obnovy nad terénom zachovaných častí}

Rekonštrukcia bola najčastejšie využívaná v prvej vlne obnov. Pozornost' sa upriamovala najmä na najvýznamnejšie a najzachovalejšie prvky, ale rekonštruované boli aj ruiny v pokro-

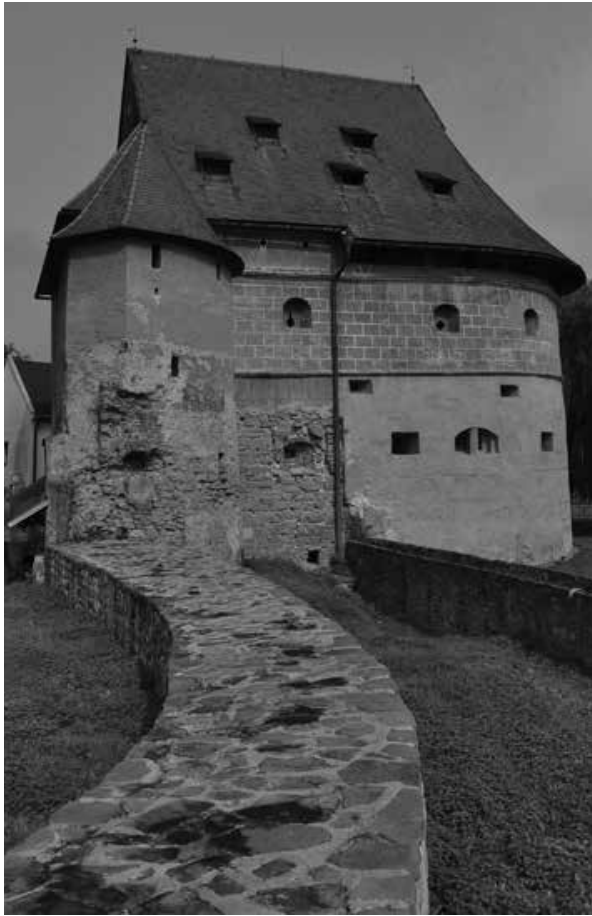

Obr. 26. Hrubá a Malá bašta opevnenia v Bardejove. Rekonštruované boli v 50. rokoch 20 . storočia. Foto A. Škrinárová.

Abb. 26. Großbastion und Kleine Bastion der Befestigung in Bardejov. Ihre Rekonstruktion erfolgte in den fünfziger Jahren des 20. Jhdts. Foto A. Škrinárová. čilej fáze deštrukcie. Rekonštrukcii väčšinou nepredchádzali potrebné výskumy a obnovovali sa touto metódou aj prvky a detaily, o ktorých nebolo dostatok exaktných poznatkov. Dôvodom pre rekonštrukciu bola najmä nová funkčná náplň objektov (múzeum, občerstvenie, archív a i.). Vo väčšine prípadov použité technológie narušili pôvodnú autenticitu originálu a do vel'kej miery znemožnili ich d'alšie skúmanie. $\mathrm{V}$ druhej vlne obnov sa pokračuje v rekonštrukcii už obnovených častí, korigujú sa podl'a nových poznatkov, získaných podrobnými výskumami. K celkovej slohovej rekonštrukcii torz vo fáze deštrukcie $\mathrm{D}$, E a F (pozri tab. I) sa už nepristupuje, nakol'ko spravidla nie je dostatok poznatkov o ich predchádzajúcej podobe.

Príkladom využitia rekonštrukčných metód na mestských opevneniach sú bašty a veže v Bardejove. Murované konštrukcie objektov boli zachované vo vel'kom rozsahu, po požiaroch však boli zastrešované novodobými krovmi. Po prvýkrát boli postupne obnovované v 50. a 60. rokoch 20. storočia (Severná, Hrubá, Školská, Červená, Prašná bašta a i.). Ich hmota sa rekonštruovala do slohovej podoby na základe čiastkových výskumov, ale aj analogicky a s využitím dobových vyobrazení. Na statické zabezpečenie sa využívali novodobé konštrukcie a materiály. Stavby, ktoré boli po zániku funkcie pristavané k objektom opevnenia a na jeho plochách boli systematicky odstraňované (obr. 26). V druhej etape obnovy opevnenia sa pristupuje najmä k prezentácii nad terénom nezachovaných častí opevnenia, ale aj ku korekcii obnov niektorých bášt a veží z prvej etapy (Červená, Renesančná bašta a i.). 


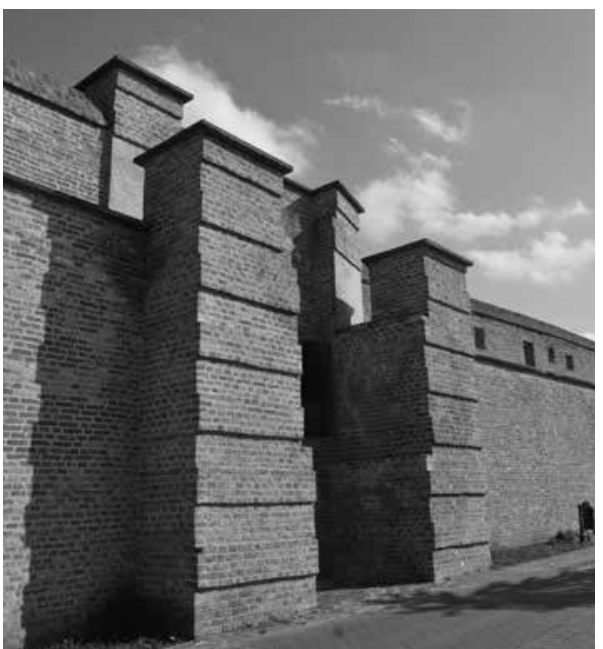

Obr. 27. Veža mestského opevnenia v Trnave upravená do podoby architektonizovanej ruiny. Horizontálne pásy zubovania tehlových riadkov predstavujú náznak pokračovania pôvodnej konštrukcie. Nezachované časti murív veže sú prezentované v dlažbe. Foto A. Škrinárová.

Abb. 27. In die Form einer architektonisierten Ruine gebrachter Turm der Stadtbefestigung in Trnava. Die horizontalen Bänder der Ziegelreihenzahnung deuten eine Fortsetzung der ursprünglichen Konstruktion an. Die nicht erhalten gebliebenen Teile des Turmmauerwerks werden im Pflaster wiedergegeben. Foto A. Škrinárová.
Konzervácia sa v prvej vlne obnov používala výnimočne, v súčasnosti sa využíva pri obnovách autenticky zachovaných prvkov. Zo statických dôvodov je však väčšinou sprevádzaná čiastočným dopíňaním ruiny (nadmurovanie, domurovanie líca a i.), prípadne sa z prezentačných dôvodov pristupuje $\mathrm{k} \mathrm{tzv}$. architektonizácii ruiny.

Príkladom architektonickej ruiny môže byt' unikátne tehlové opevnenie mesta Trnavy. Od 70. rokov 20. storočia sa pristúpilo k čiastkovej obnove niektorých úsekov. V druhej polovici 90. rokov bola vypracovaná koncepcia obnovy mestského opevnenia (GregorováGregor-Staník a kol. 1996), ktorá bola spracovaná $\mathrm{v}$ súlade $\mathrm{s}$ už zrealizovanými obnovami hradieb z predošlého obdobia. Základnou metódou obnovy nadzemných murovaných konštrukcií je konzervačná metóda kombinovaná s rekonštrukčnou metódou (obr. 27). Prvky zachované len pod úrovňou terénu sú po archeologickom výskume odborne ošetrené, prekryté a v úrovni terénu naznačené vyložením pôdorysu príslušnej murovanej časti opevnenia inou dlažbou. Chýbajúce časti opevnenia $\mathrm{v}$ úsekoch, kde si to vyžadovala okolitá urbanistická situácia, boli čiastočne vystavané náznakovou rekonštrukciou v hmote ako tehlový neomietaný novotvar (Gregorová-Gregor-Staník a kol. 1996; Kvetanová a kol. 2012, 142). Ciel’om takto volenej obnovy a architektonizácie mestského opevnenia v urbanistickej mierke, ale aj v detaile je zlepšenie čitatel'nosti pôvodnej situácie a typológie opevnenia a jeho prezentácia v čo najväčšej miere.

\section{Metódy obnovy nad terénom nezachovaných častí}

Archeologické nálezy prvkov opevnenia nezachovaných do úrovne terénu sú väčšinou konzervované a znovu zasypané. Ich prezentácia potom môže spočívat' v náznakovej rekonštrukcii. Ide o štylizáciu zaniknutého prvku v priestore, alebo ak to súčasná situácia neumožňuje, aspoň $\mathrm{v}$ polohe vyloženia v pôdorysnej stope inou dlažbou na teréne. Príkladom tejto metódy je severný úsek mestského opevnenia v Sabinove. Archeologicky doložený priebeh priamych úsekov opevnenia a troch polygonálnych bášt alebo veží je prezentovaný nízkym múrikom z lomového kameňa (obr. 28).

Pri archeologických nálezoch prvkov opevnenia sa v menšej miere uplatňuje prezentácia $\mathrm{v}$ pôvodnej nivelete terénu. Konzervovaný originál býva prekrytý krycou stavbou, ktorá tvorí dištančný článok medzi rôznymi úrovňami terénu. Takáto prezentácia je uplatnená vo viacerých polohách mestského opevnenia v Košiciach. Pod hlavnou ulicou je zriadené Archeologické múzeum, ktoré v pôvodnej polohe prezentuje originálne konštrukcie komplexu Dolnej brány so stredovekou bránovou vežou a neskôr dobudovaným predbráním, barbakánom, rondelom a nadväzujúcimi obrannými prvkami. Na súčasnom teréne sú priebehy murív prezentované zmenou dláždenia a cez svetlíky je možné vidiet' originálne konštrukcie (obr. 29). 


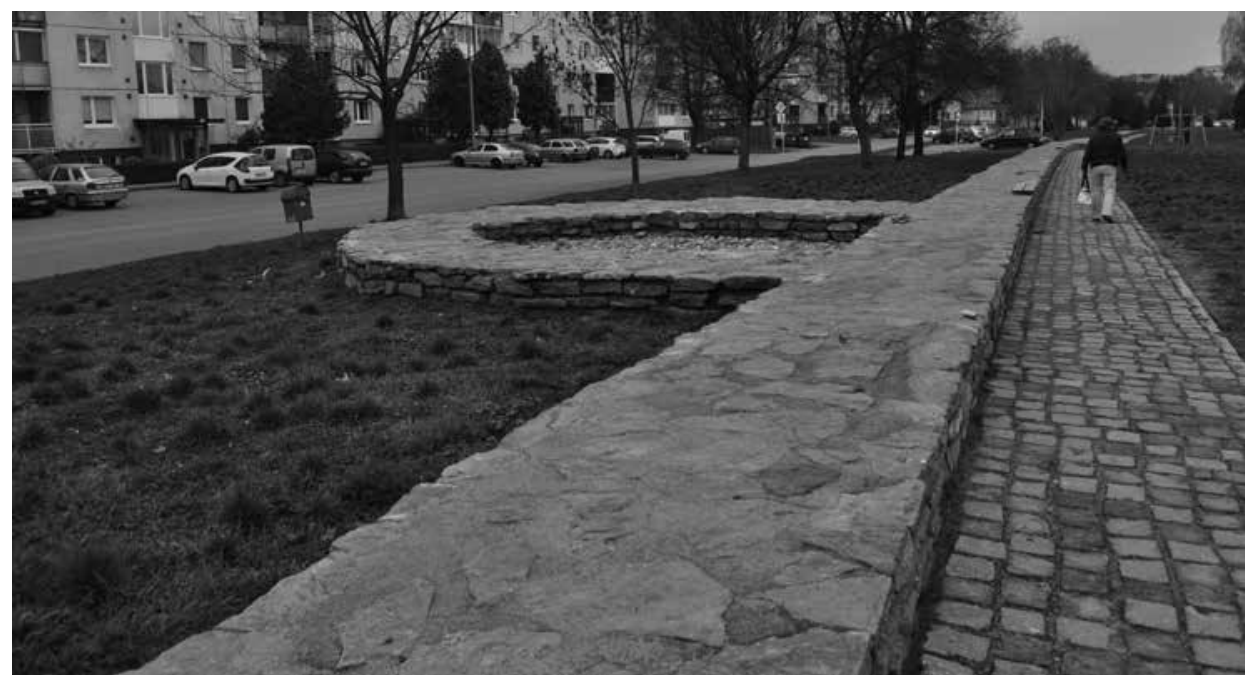

Obr. 28. Severný úsek opevnenia v Sabinove. Po archeologickom výskume bol prezentovaný náznakom pôvodného pôdorysu kamenným múrikom. Foto A. Škrinárová.

Abb. 28. Nördlicher Abschnitt der Befestigung in Sabinov. Nach der archäologischen Grabung wurde der ursprüngliche Grundriss durch eine niedrige Mauer angedeutet. Foto A. Škrinárová.

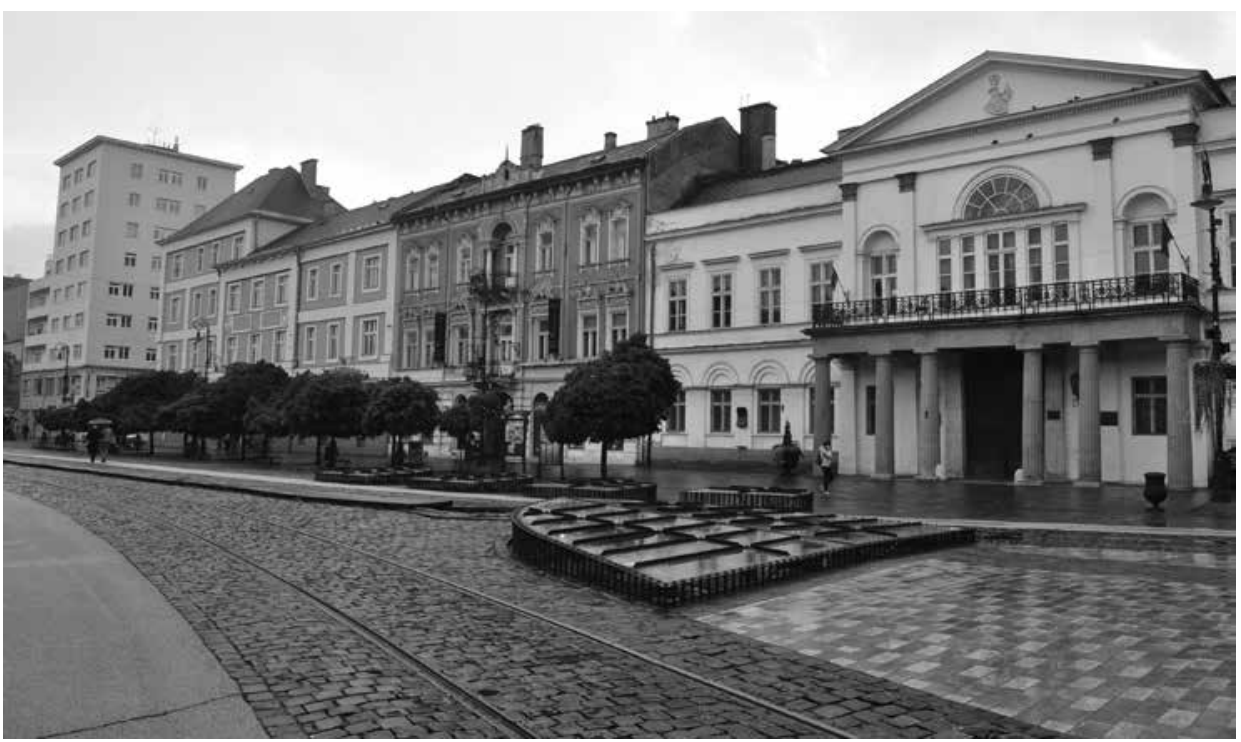

Obr. 29. Komplex Dolnej brány v Košiciach. Zakonzervovaný originál je prezentovaný in situ v pôvodnej nivelete pod úrovňou súčasnej ulice v Archeologickom múzeu. Murivá je vidiet’ aj cez svetlíky z úrovne ulice. Foto A. Škrinárová.

Abb. 29. Komplex des Unteren Tores in Košice. Das konservierte Original wird im unterirdischen archäologischen Museum im ursprünglichen Höhenverlauf unter der heutigen Straße in situ präsentiert. Das Mauerwerk ist durch die Oberlichter auch von der Straße aus zu sehen. Foto A. Škrinárová.

V kombinácii s vyššie uvedenými metódami sa využívajú aj rôzne symbolické znázornenia, umelecké prvky a informačné systémy poukazujúce na polohu významných prvkov opevnenia. Príkladom je spôsob dodatočného zjednotenia informácie o polohe všetkých brán mestského opevnenia v Bratislave. Systém opevnenia mesta mal štyri mestské brány. Michalská je jednou z mála brán na Slovensku, kde sa zachoval aj barbakán s častou priekopy. Ostatné brány sa do 


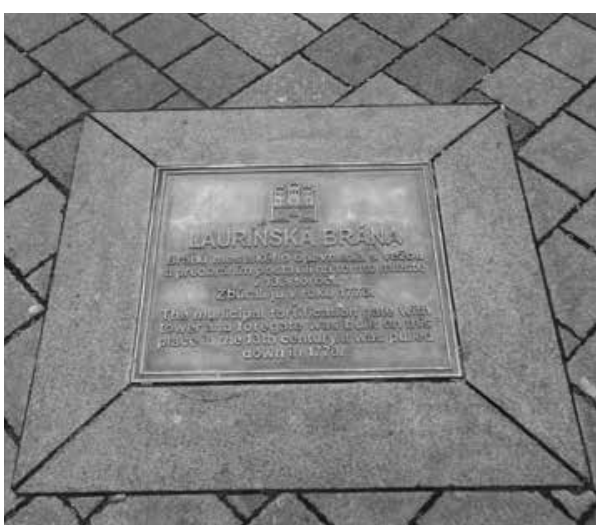

Obr. 30. Naznačenie polohy Laurinskej brány. Pre zjednotenie prezentácie je v mieste všetkých brán v dlažbe vložená informačná tabul'a. Foto J. Gregorová.

Abb. 30. Angedeutete Lage des Lorenztors. Zwecks einheitlicher Präsentation wurde an allen Toren eine Informationstafel in das Pflaster eingelassen. Foto J. Gregorová.

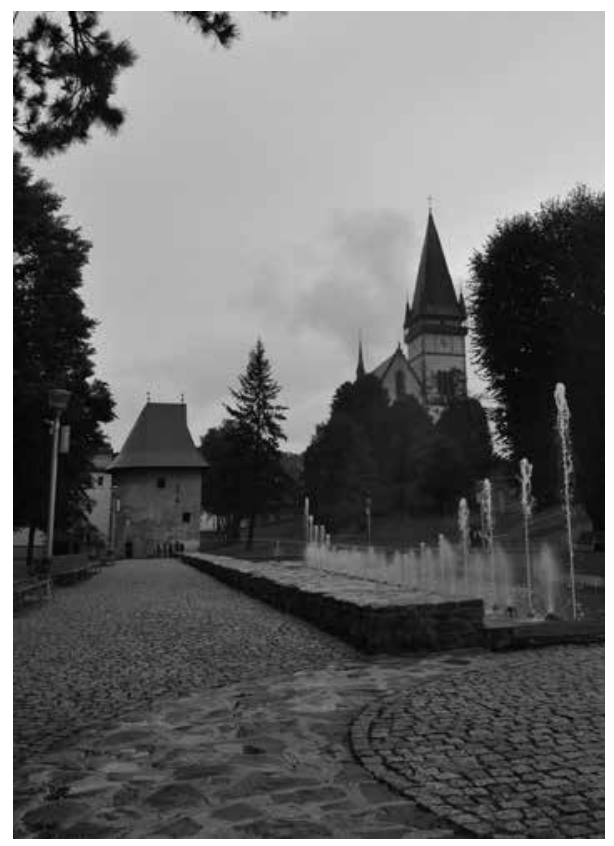

Obr. 31. Štylizovaná prezentácia vodnej priekopy a mlynského náhonu $v$ severnom úseku opevnenia $v$ Bardejove. Foto A. Škrinárová.

Abb. 31. Stilisierte Präsentation des Wassergrabens und Mühlbachs im nördlichen Abschnitt der Befestigung in Bardejov. Foto A. Škrinárová. súčasnosti nad terénom nezachovali. Ich poloha je overená archeologickými výskumami. Pri rekonštrukcii verejných priestorov však nedošlo k ich prezentácii v úrovni terénu. Čast' Rybárskej brány je prezentovaná $\mathrm{v}$ autentickej podobe pod presklenou krycou konštrukciou na Hviezdoslavovom námestí. Poloha Laurinskej brány je zvýraznená zaveseným prvkom evokujúcim padaciu mrežu. Vydrickú bránu nad úrovňou terénu predstavuje len fragment muriva vystupujúci z líca hradby západného úseku na Rybnom námestí. Pre zjednotenie prezentácie všetkých štyroch lokalít brán ${ }^{10}$ boli v ich polohách dodatočne vsadené v dlažbe informačné tabule (obr. 30).

\section{Metódy prezentácie plôch opevnení}

Medzi bývalé plochy opevnenia patrí najmä priestor parkánu a priekopy v predpolí opevnenia a priestor manipulačnej hradbovej uličky vo vnútri mesta. Pri každom opevnení mali tieto plochy špecifickú výškovú úroveň vychádzajúcu $\mathrm{z}$ konfigurácie terénu a snahy znemožnit' nepriatel'ovi prístup $\mathrm{k}$ hradbám. V súčasnosti väčšina týchto plôch nemá pôvodnú profiláciu a ich prezentáciu komplikuje novšia zástavba. Najmä v 60.-80. rokoch 20. storočia sa pristupovalo $\mathrm{k}$ rozsiahlej asanácii zástavby, ktorá vznikla po zániku obrannej funkcie opevnenia a na uvol'nených miestach sa zriad'ovali parky (Levoča, Trnava a i.), prípadne zatrávnené plochy. $\mathrm{V}$ súčasnosti už búranie $\mathrm{v}$ takomto rozsahu nie je možné, nehodnotné stavby zabraňujúce prezentácii sa určujú na dožitie (Bardejov a i.). V miestach, kde je to možné, sa pristupuje k náznakovej prezentácii bývalých plôch opevnení. $\mathrm{Na}$ prezentáciu hradbových uličiek býva použité odlišné dláždenie, v miestach priekop sa umiestňujú zelené plochy, prípadne diela evokujúce fenomén vody. Príkladom je severozápadná čast' priekopy opevnenia v Bardejove, kde je archeologicky doložená vodná priekopa a poloha mlynského náhonu štylizovaná ako fontána, doplnená náznakovou prezentáciou murovaných prvkov (obr. 31).

10 Autormi koncepcie a návrhu prezentácie osadením kovových platní boli P. Baxa a J. Gregorová. Realizácia prebehla v roku 2002. 


\section{Špecifický prístup architekta}

Prínos architekta vo vzt’ahu k mestským opevneniam spočíva v chápaní urbanistickej aj architektonickej dimenzie, ktorou je tento typologický druh špecifický. Pri obnove architekt berie do úvahy okrem pamiatkových hodnôt aj urbanistické vzt’ahy s okolím, dopravné napojenie (doprava po vonkajšom okruhu a v hradbovej uličke, pešie komunikácie, ochodza a i.), okolitú zástavbu a novú funkčnú náplň objektov a pril’ahlých plôch.

Podobne ako pri hradoch okrem ochrany zabezpečuje aj prezentáciu originálu. Rôznymi formami náznaku, výtvarným dielom, tvarovaním terénu a i. naznačuje zaniknuté javy pre opätovné definovanie nadväznosti prvkov a primeranú prezentáciu komplexu ako celku. Na rozdiel od hradných komplexov nachádzajúcich sa prevažne v krajinnom prostredí (kde aj chátrajúce murivá vytvárajú dostatočne odlišnú a tým čitatel'nú skupinu v prostredí), je prezentácia častí pôvodnej ucelenej línie opevnenia $\mathrm{v}$ zastavanom sídelnom kontexte ovel'a problematickejšia (nečitatel'nejšia). Hlavným ciel'om architekta (urbanistu) je preto jeho zvýraznenie ako líniového prvku, vymedzujúceho historické mesto od okolia.

\section{Záver}

Problematika metodického projektovania pri obnove torz prezentovaná $\mathrm{v}$ tomto príspevku je chápaná ako výsledok úzkej spolupráce medzi projekčnou a metodickou zložkou spomínaného procesu. Ak sa v minulosti (v dobe existencie štátneho pamiatkového ústavu a štátnych projekčných zložiek špecializovaných na obnovu pamiatok) postupne vyprofilovali architekti, ktorí spolu s metodikmi tvorili výslednú podobu pamiatkovej obnovy, tak v súčasnosti (vznikom štátnych pamiatkových úradov a individuálnych projektantov) sa profilovanie architektov výrazne zmenilo (skomplikovalo). V predošlom období štátne inštitúcie zabezpečovali výskumnú, metodickú aj projekčnú zložku, čím vznikali pomerne jednotné názory na optimálny spôsob obnovy pamiatkových štruktúr. V súčasnosti sa výskumná a projekčná zložka individualizuje, štátna zložka zabezpečuje metodiku (vlastne koordináciu procesu). Zvýšením miery individualizácie v spomínanom procese sa rôznia aj názory na obnovy. Ak sa do prvej polovice 20. storočia úloha architekta pri konzervačných a rekonštrukčných postupoch nejavila ako nutná, tak v druhej polovici tohto storočia sa architektonizácia pamiatok v duchu modernizácie tradičných štruktúr rozšírila natol'ko, že sa výrazná čast' pamiatkového fondu narušila, prípadne úplne zanikla.

Možno aj obava pred d’alšími stratami je dôvodom, prečo sa v súčasnosti znižuje podiel architektov na obnove torz architektúry. Hladanie nových empatických riešení zohl'adňujúcich dominanciu originálu a reverzibilnost' nových konštrukcií by mohlo byt' cestou k náprave. Budúcnost' ukáže, či sa pri obnove pamiatok bude požadovat' profesionalita všetkých odborných zložiek alebo len niektorých, ktoré momentálne definujú relevantné zákony.

\section{Pramene a literatúra}

ASHURST, J., 2007: Conservation of ruins. Oxford.

BUDAY, P., 2013: Obnova „Pribinovho kostola“ na Nitrianskom hrade v rokoch 1931 až 1933, Monument revue $2,2-7$.

DVOŘÁKOVÁ, V.-ANDRÁŠI, P. a kol., 2012: Bratislava - pamiatková rezervácia. Zásady ochrany pre vybrané sektory pamiatkovej rezervácie, PÚ SR, Bratislava, http://www.pamiatky.sk/sk/page/zasady-ochrany-pr-bratislava, cit. 10. 11. 2014.

ĎURIŠOVÁ, M., 2004: Opevnenie Košíc - Befestigung der Stadt Košice, AH 29, 249-356.

GIRSA, V.-HANZL, M., 2011: Typologie obnovy. Praha.

GLOS, P. a kol., 2006-2009: Pamiatková rezervácia Bardejov. Zásady ochrany pamiatkového územia, KPÚ Prešov, http://www.pamiatky.sk/sk/page/zasady-ochrany-pr-bardejov, cit. 10. 11. 2014.

GREGOROVÁ, J., 2002: Prezentácia torz architektúry, habilitačná práca. Bratislava. 
- 2007: Aj ruina môže byt' predmetom architektonického navrhovania, Projekt - slovenská architektonická revue $49,5-6,62-67$.

GREGOROVÁ, J. a kol., 2003: Prezentácia architektonického dedičstva. Bratislava.

GREGOROVÁ, J. a kol., 2013: Modra - hradby, predprojektová príprava pre začatie obnovy NKP mestského opevnenia v Modre. Bratislava.

GREGOROVÁ, J.-GREGOR, P. a kol., 2008: Prezentácia architektonického dedičstva II. Bratislava.

GREGOROVÁ, J.-GREGOR, P.-STANÍK, I. a kol., 1996: Regulatívy pamiatkovej obnovy a revitalizácie hradobného systému MPR Trnava. Bratislava.

GREGOROVÁ, J.-KOHÚT, V. a kol., 2014: Modra - hradby, predprojektová príprava pre začatie obnovy NKP mestského opevnenia v Modre, čast': Statický prieskum pre urbanistický koncept obnovy. Bratislava.

GREGOROVÁ, J.-PETRÁŠOVÁ, S.-ŠKRINÁROVÁ, A., 2014: Prezentácia NKP mestského opevnenia v pamiatkovej zóne Modra a jeho prilahlej zástavby. Bratislava.

HOFEREK, A.-KOHÚT, V.-MAKÝŠ, O., 2006: Dominanty v krajine - zrúcaniny hradov a ich ochrana. In: Ochrana zrúcanín v kultúrnej krajine, 14-27. Lietava.

HOLEČEK, J.-GIRSA, V. a kol., 2008: Projektování obnovy stavebních památek. Praha.

KVETANOVÁ, G. a kol., 2012: Mestská pamiatková rezervácia Trnava. Urbanisticko-historický výskum a aktualizácia zásad ochrany pamiatkového územia, KPÚ Trnava, http://www.pamiatky.sk/sk/page/ zasady-ochrany-pr-trnava, cit. 10. 11. 2014.

KYJOVSKÁ, V., 2012: Neinvazívne spôsoby prezentácie ruín architektúry - virtuálna prezentácia zanikajúcej architektúry, dizertačná práca, FA STU Bratislava.

PALGUTOVÁ, K., 2014: Analytická metóda prezentácie pamiatok a jej potenciál v procese architektonickej tvorby, dizertačná práca, FA STU Bratislava.

PLAČEK, M.-BÓNA, M., 2007: Encyklopédia slovenských hradov. Bratislava.

STANÍK, I., 2008: Pôvodný zámer výstavby stredovekého opevnenia Trnavy a jeho postupná realizácia. In: Forum urbes medii aevi V. Městské fortifikace ve vrcholně středověkých zeměpanských městech střední Evropy, 52-85. Brno.

STANÍK, I.-GREGOROVÁ, J. a kol., 2014: Mestské opevnenie Modra. Modra.

ŽKÍCENINY, 1998: Zříceniny historických staveb a jejich památková ochrana. Př́iloha ZPP 58. Praha.

\section{Zusammenfassung}

\section{Die Restaurierung von Architekturtorsi als architektonische Spezialdisziplin}

In dem hier vorgelegten Beitrag wird der Versuch unternommen, die unter Berücksichtigung des Störungsgrades von sich in urbanisierten oder landschaftlichen Kontexten befindenden, ursprünglich zweckgebundenen Bauten, Arealen, ggf. ganzen urbanistischen Systemen erworbene Spezifität des Architektenberufs bei der Restaurierung von Architekturtorsi zu charakterisieren. Neben einer allgemeinen Charakteristik der jeweils vorliegenden Probleme wird auch eine Modelllösung für den Entwurf einer komplexeren Restaurierung der Stadtbefestigung im Denkmalschutzgebiet Modra vorgestellt, an welcher einige Mitglieder des Autorenkollektivs in den Jahren 2012-2014 beteiligt waren.

Bei der Planung einer Restaurierung muss auf eine sensible und verständliche Präsentation des Denkmals und auf eine bestmögliche Erhaltung seiner Authentizität geachtet werden. In der Praxis werden für die betreffende Tätigkeit jedoch weder in der Slowakei noch in Tschechien Spezialisten dieser Art aus den Reihen der Architekten gefordert. Ohne eine reibungslose Koordination der Abläufe und ohne Kenntnisse über traditionelle Technologien und bauliche Verfahren entsteht im Planungsprozess und in der anschließenden Realisierung eine unnötig komplizierte Situation, durch welche die Kontinuität des Restaurierungsprozesses gebremst wird.

Die Aufgabe des Architekten im Restaurierungsprozess von Denkmälern hat in jeder Etappe seinen speziellen Platz. Die Komplexheit dieses Berufs findet ihre praktische Umsetzung in der Erforschungsphase eines Denkmals, in deren Interpretation, beim Entwurf der Restaurierungsmethode, bei der Ausarbeitung aller Stufen der Planungsdokumentation sowie während der Aufsicht durch den Architekten bei der Realisation selbst. Der Architekt ist Teil eines inter- 
disziplinären Teams, dessen Hauptziel darin besteht, die optimale Restaurierung eines Denkmals zu planen und zu realisieren, wobei der Schwerpunkt auf einer bestmöglichen Erhaltung seiner Authentizität sowie auf Verständlichkeit seiner Präsentation liegt. Gleichzeitig ist das Team während den Arbeiten an der Planungsdokumentation dafür verantwortlich, in jeder Stufe die Kontinuität mit ausgearbeiteten Gebietsplänen oder sonstigen Typen einer Planungsdokumentation zu gewährleisten.

Seit 2002 wird an der Fakultät für Architektur der Slowakischen Technischen Universität in Bratislava für Architekten die systematische Lehre mit Studienschwerpunkt Restaurierung von Architekturtorsi angeboten. Es wurden Skripte ausgegeben, Beiträge in Fachzeitschriften veröffentlicht, und die Problematik wurde auf wissenschaftlichen Konferenzen vorgetragen. In Zusammenarbeit mit den Kreisdenkmalämtern werden die Pläne für einzigartige und häufig auch international bedeutende archäologische Fundstellen ausgearbeitet. Für die betreffende Problematik werden Doktorandenteams ausgeschrieben, von denen Teilprobleme gelöst werden, die mit der Präsentation von Architekturtorsi zusammenhängen. Im zweiten Teil des vorliegenden Beitrags werden einige solcher Teilergebnisse präsentiert.

In der Dissertation Schutzkonstruktionen und Überdachungsbauten von Architekturtorsi sind solche Objekte Forschungsgegenstand, die national und international bedeutende Denkmäler sowie die ältesten Denkmäler einschießlich ihre seltenen dekorativen Elemente in situ schützen. Die Schutzkonstruktionen eines Torsos können hinsichtlich ihrer Methode der Denkmalrestaurierung als exakte, analoge, hypothetische oder angedeutete Stilrekonstruktion konzipiert werden. Überdachungsbauten von archäologischen Fundstellen werden in neuen Formen entworfen. Der Architekt trägt bei ihrer Gestaltung der Erhaltung des Torsos, seinem Bezug zur Umgebung und seiner angemessenen Präsentation und Interpretation Rechnung. Er ist an der Gestaltung der Restaurierungsmethode, an den Vorplanungen und Planungsarbeiten bis hin zur Bauaufsicht beteiligt. Im gesamten Prozess arbeitet er mit einem Verfahrenstechniker, Stadtplaner, Landschaftsarchitekten und mit verschiedenen Fachberufen zusammen, um eine optimale Umgebung zu schaffen, damit das Original erhalten bleibt und eine adäquate Präsentation erreicht wird.

Ziel der Dissertation mit dem Titel Die Restaurierung von Burgen auf dem Gebiet der Slowakei ist es, eine Methodik zur Bestandsuntersuchung und Dokumentation von Burgrestaurierungen zu schaffen, typische Restaurierungsbeispiele dafür zu finden und nachzuzeichnen, welche Herangehensweise von den Architekten bei solchen Restaurierungen in den einzelnen Epochen jeweils zugrunde gelegt wurde. Die Ansichten über die Restaurierung von Burgen entwickeln sich ständig weiter. Auf dem Gebiet der Slowakei erfolgten die ersten Restaurierungen bereits im 19. Jahrhundert. Seit Anfang des 20. Jahrhunderts können wir ganze Schübe von Burgrestaurierungen beobachten, die durch die jeweils bevorzugte Restaurierungsmethode charakteristisch sind und sich dadurch voneinander unterscheiden, dass diese Methode geändert wurde oder die Restaurierungen nicht zu Ende geführt wurden. Die heutige Burgrestaurierungswelle wurde nach dem Jahr 2002 in Gang gesetzt. Bei den Restaurierungen wird deutlich eine konservierende Methode bevorzugt, was zur Folge hatte, dass die Beteiligung des Architekten bei der Restaurierung minimiert wurde. Eine kleinere Gruppe stellen Burgen dar, bei denen die Restaurierung des Originals mit kontrastiv wirkenden auffälligen neuen Formen durchgeführt wurde. Dabei handelt es sich ausschließlich um Burgen, die in der Vergangenheit bereits restauriert worden waren und deren Authentizität durch vorher angewandte stilwidrige technologische Verfahren gestört wurde.

Im Rahmen der Doktorandenuntersuchung mit dem Titel Die Restaurierung von mittelalterlichen Stadtbefestigungen auf dem Gebiet der Slowakei werden in Form einer Bestandsaufnahme die Erkenntnisse über erhaltene Befestigungen aus jenem Zeitraum und deren Restaurierung zusammengefasst. Nachdem sie ihre Verteidigungsfunktion eingebüßt hatten, wurden sie nach und nach abgerissen und sind bis heute in jeweils unterschiedlichem Zustand erhalten geblieben. Ihr Erhaltungsgrad kann in städtebaulichen und architektonischen Dimensionen beobachtet werden. Der Architekt zieht im Rahmen einer Denkmalrestaurierung alle Methoden 
der Denkmalrestaurierung heran und gewährleistet neben dem Schutz auch die Präsentation des Originals. Er operiert dabei mit verschiedenen Formen des Anklangs, mit plastischen Werken, mit der Gestaltung des Geländes u.a., um verschwundene Erscheinungsformen anzudeuten, den Kontext der einzelnen Teilelemente neu zu definieren und den Komplex als Ganzes angemessen zu präsentieren.

Doc. Ing. arch. Jana Gregorová, PhD., Fakulta architektúry Slovenskej technickej univerzity v Bratislave, Námestie slobody 19, SK 81245 Bratislava 1,gregorova@fa.stuba.sk

Ing. arch. Lýdia Chovancová, doktorand, Fakulta architektúry Slovenskej technickej univerzity v Bratislave, Námestie slobody 19, SK 81245 Bratislava 1, chovancova.lydia@gmail.com

Ing. arch. Zuzana Ondrejková, doktorand, Fakulta architektúry Slovenskej technickej univerzity v Bratislave, Námestie slobody 19, SK 81245 Bratislava 1, ondrejkova.zuz@gmail.com

Ing. arch. Alexandra Škrinárová, doktorand, Fakulta architektúry Slovenskej technickej univerzity v Bratislave, Námestie slobody 19, SK 81245 Bratislava 1, alex.skrinarova@gmail.com 
